\title{
Diphenyl Diselenide a Janus-Faced Molecule
}

\author{
Cristina W. Nogueira* and João B.T. Rocha* \\ Departamento de Química, Centro de Ciências Naturais e Exatas, \\ Universidade Federal de Santa Maria, 97105-900 Santa Maria-RS, Brazil
}

\begin{abstract}
Este artigo de revisão aborda uma reflexão sobre o potencial terapêutico ou tóxico de compostos orgânicos de selênio, dando particular ênfase ao disseleneto de difenila e alguns dos seus análogos estruturais. Algumas características moleculares relacionadas com a toxicidade e farmacologia do disseleneto de difenila in vitro e in vivo são abordadas. Os artigos revisados, que abordam experimentos in vivo, indicam que a interação do disseleneto de difenila com tióis pode determinar seu potencial farmacológico ou toxicológico. Além disso, uma limitada ativação da rota de toxicidade, isto é, a oxidação controlada de moléculas de alto peso molecular, que contém grupos tióis, poderia contribuir para os efeitos farmacológicos do disseleneto de difenila. Concluise que a síntese de compostos orgânicos de selênio deve ser direcionada para o desenvolvimento de novos disselenetos de diorganoila que possam interagir com alvos moleculares específicos.
\end{abstract}

In this review, we summarized the potential role of synthetic organoseleno compounds as therapeutic or toxic agents, giving emphasis almost exclusively to diphenyl diselenide, the simplest of the diaryl diselenides, and some of its analogs. We presented the main molecular aspects related to the in vitro toxicity and pharmacology of diphenyl diselenide and also provided in vivo data indicating that the interaction of diphenyl diselenide with thiols can dictate either its toxicological or pharmacological property. The papers covered in this review indicate that a limited activation of the "toxic pathway", i.e., a controlled oxidation of specific high molecular weight thiol-containing molecules could contribute to the pharmacological effects of diphenyl diselenide. In conclusion, this review reinforces the necessity of developing new diorganoyl diselenides that could interact with specific molecular targets.

Keywords: selenium, toxicity, pharmacology, thiol, diphenyl diselenide

\section{Introduction}

Selenium is a fundamental component of the living cells of a variety of organisms and, as it will be briefly summarized in the next section, it is found in a limited number of molecules and will interact only with few functional groups of biomolecules (thiol-thiolate groups) or with strong pro-oxidant peroxides. ${ }^{1}$ Although selenium has important physiological roles in mammalian cell, it is still debatable whether exposure to selenium levels slightly above the nutritional requirements can be beneficial or hazardous to human population. ${ }^{2}$ In this review, we will summarize the potential role of synthetic organoseleno compounds as therapeutic or toxic agents, giving emphasis almost exclusively to diphenyl diselenide, the simplest of the diaryl diselenides, and some of its analogs. In fact, the

*e-mail: jbtrocha@yahoo.com.br interest in the biochemistry, pharmacology and toxicology of organoseleno compounds has increased from the 80s, when literature data demonstrated that ebselen was a promising antioxidant and mimetic of the antioxidant selenoenzyme glutathione peroxidase. ${ }^{3}$

Based on the neuroprotective effects of ebselen in rodent models of brain ischemia, it was used in clinical trials for the treatment of neurological diseases associated with ischemia and oxidative stress. ${ }^{4}$ The results indicated a borderline efficacy for ebselen and it was the first time that a synthetic selenoorgano compound was used with relative success in human trials.

At that time, we were essentially interested in the potential toxic properties of diphenyl diselenide; however, based on these promising results with ebselen in animal models and in human trials and, considering the fact that diphenyl diselenide could be a more efficient mimetic of native glutathione peroxidase than ebselen, ${ }^{5}$ we also 


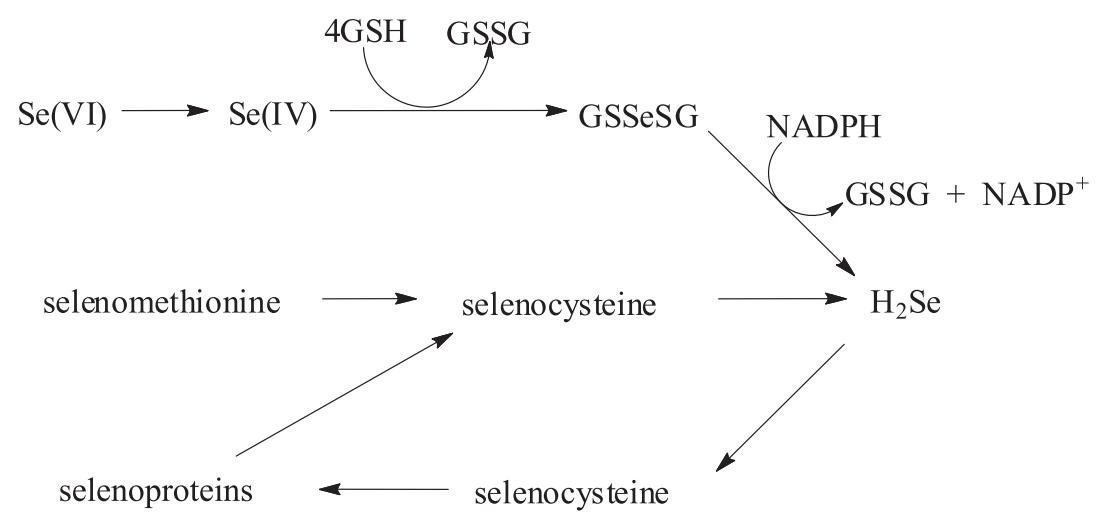

Figure 1. Schematic fate of Se(IV), selenomethionine and selenocysteine liberated from selenoproteins. The enzymatic reduction of Se $\mathrm{e}^{4+}$ to $\mathrm{Se}^{2-}$ is carried out by reduced glutathione (GSH). Adapted from Pinheiro and co-workers. ${ }^{7}$

started to investigate the antioxidant and pharmacological properties of diphenyl diselenide. ${ }^{6}$ In this review, we will present the main molecular aspects related to the in vitro toxicity and pharmacology of diphenyl diselenide and also will provide in vivo data indicating that the interaction of diphenyl diselenide with thiols can dictate either its toxicological or pharmacological property.

\section{In Vitro Biochemistry}

\subsection{Biological chemistry of selenium in mammalian cells}

Before starting the main subject of this review, i.e., the molecular aspects that can determine the toxicity and potential therapeutic use of diphenyl diselenide and analogs, we will present a brief review of the "natural or physiological chemistry" of selenium in mammalian cells to illustrate to the readers that "synthetic or pharmaceutical chemistry" of diphenyl diselenide shares some similarities with that of "natural chemistry" of selenium or with selenium role in selenoproteins.

The "natural biological chemistry" of selenium is dictated by its incorporation into selenoproteins. The process is complex and involves several enzymatic steps. ${ }^{7}$ Figure 1 presents schematic pathway of inorganic selenium $\left(\mathrm{Se}^{4+}\right)$ and selenomethionine incorporation in selenoproteins and the final product that will be incorporated in the growing polypeptide chain of a selenoprotein is the amino acid selenocysteine (Figure 2), an analog of cysteine and serine. However, we must emphasize here that selenocysteine is not found in a free pool before the incorporation in the nascent peptide. Indeed, selenocysteine is formed after incorporation of the selenium atom from a selenophosphate into a serinyl residue that is previously bound to a specific $t$-RNA. The reasons why selenocysteine does not exist in a free pool certainly is related to its instability and high reactivity of selenol groups and a circulating pool of selenocysteine in mammalian body should be selenocystin. Furthermore, the selenocysteine residues liberated after degradation of selenoproteins must be first metabolized to inorganic selenium to be re-incorporated in selenoproteins (Figure 1).

The first demonstration that selenium was found in proteins as selenocysteine was given in 1978 by Frostrom et $a l .{ }^{8}$ in a classic study conducted at the laboratory of Tappel. In this study, they unraveled the chemical nature of selenium isolated from the hepatic bovine glutathione peroxidase. In short, this classic study brought to the biochemical and physiological scene a new and more powerful nucleophile than the known thiol-thiolate group, i.e., the selenol-selenolate group (Figure 2).

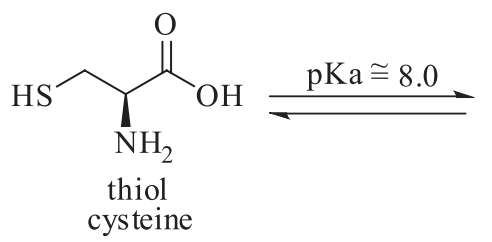<smiles>CSC[C@H](N)C(=O)O</smiles>

thiolate<smiles>N[C@H](CC#CC#C[Se]C[C@H](N)C(=O)O)C(=O)O</smiles>

Figure 2. Selenol/selenolate group of the unique endogenous selenorgano compound in mammalian cells. Analogy of selenocysteine with cysteine showing the lower pKa of selenocysteine, which indicates that at physiological $\mathrm{pH}$ the proportion of selenol-selenolate is higher than that of thiol-thiolate.

Thereafter, it was established that all the selenoproteins contain at least one selenocysteinyl residue in their structure (for a recent, elegant and concise review about selenoproteins see Lu and Holmgren ${ }^{9}$ ). For the case of the selenoenzymes, it is now well documented that the selenolselenolate group from selenocysteine plays a central role 
in the catalytic cycle of important antioxidant enzymes, such as thioredoxin reductase and glutathione peroxidase (Figure 3).

In summary, the physiological chemistry of selenium in mammalian cells relies on the presence of selenocysteine in selenoproteins. More specifically, during the catalytic cycle of glutathione peroxidase (GPx) selenoproteins, the selenolselenolate group first interacts with pro-oxidant molecules, such as hydrogen peroxide or organic hydroperoxides, forming a selenenic acid in the active center of the enzyme (Figure 3a). The oxidized selenocysteinyl residue is reduced back to selenol via a sequential interaction with two equivalents of reduced glutathione (GSH). The reaction of the first GSH with the GPx-seleninic acid forms a selenopersulfate (-C-Se-S-C-). The GPx selenopersulfate intermediate is attacked by the second GSH, which regenerates the selenol-selenolate at the active site of GPx and releases the oxidized glutathione (GSSG; Figure 3a). In the case of thioredoxin reductase (TrxR), the selenol group of the enzyme can be found forming a mixed -S-Se- bridge or as a selenol group that reduces the enzyme substrate (here the oxidized thioredoxin) to its reduced form (Figure 3b).
The catalytic cycle of TrxR is more complex than that of GPx. Indeed, the active mammalian TrxR is an asymmetric homodimer. The proposed catalytic cycle of TrxR starts with the electron transfer from the NADPH to FAD, which reduces the disulfide bond near to the $\mathrm{N}$-terminal site of the subunit. The thiol groups from N-terminal subunit interacts and reduces the selenylsulfide bond $(-\mathrm{S}-\mathrm{Se}-)$ in the opposite subunit, forming the reactive selenolate near to the carboxy-terminal portion of the $\mathrm{C}$ terminal subunit. This accessible and reactive selenol/selenolate group can reduce thioredoxin (Trx) (as indicated in Figure $3 b$ ) and a variety of substrates. ${ }^{9}$

One feature that becomes clear from the inspection of the catalytic cycles of glutathione peroxidase and thioredoxin reductase is that, at specific steps of their catalysis, an interaction between a sulfur atom from a thiol with a selenium atom from an oxidized selenocysteine will occur. Here emerges another corollary from physiological chemistry of selenium in living cells: the antioxidant activity of selenium involves the formation of a bond of the type $\mathrm{R}^{1}-\mathrm{Se}-\mathrm{S}-\mathrm{R}^{2}$ (where $\mathrm{R}^{1}$ is obligatorily a high molecular weight selenoprotein or selenoenzyme and $\mathrm{R}^{2}$ can be either

a)

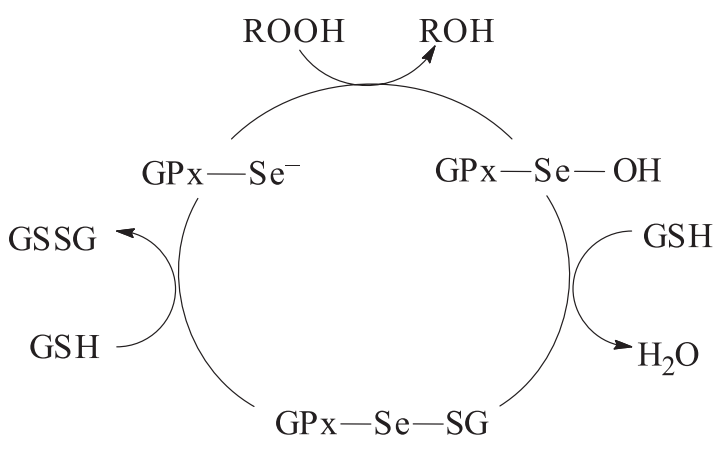

b)

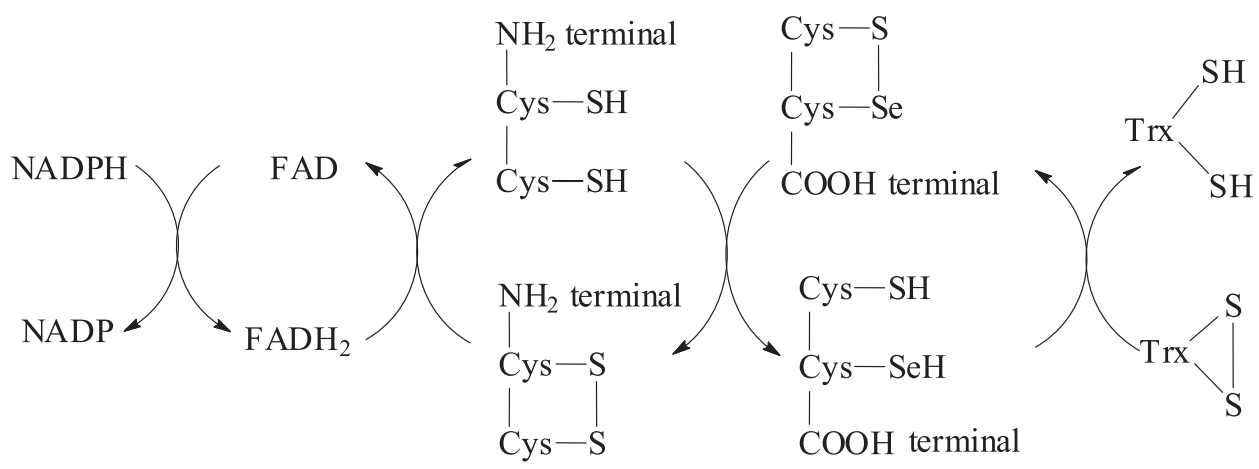

Figure 3. Catalytic cycle of the selenoenzymes, gluthathione peroxidase, GPx (a) and thioredoxin reductase, TrxR (b). In Figure 3a, the selenolate group reacts with hydrogen peroxide or organic hydroperoxides, forming a selenenic acid. The reaction of the first GSH with the GPx-seleninic acid forms a selenopersulfate (-C-Se-S-C-). The GPx selenopersulfate intermediate is attacked by the second GSH, which regenerates the selenolate at the active site of GPx and releases GSSG. In Figure 3b, the catalytic cycle of TrxR starts with the electron transfer from the NADPH to FAD, which reduces the disulfide bond. The thiol groups from $\mathrm{N}$-terminal subunit reduce the selenylsulfide bond (-S-Se-) in the opposite subunit, forming the reactive selenolate, which reduces thioredoxin. 
a low molecular weight thiol, such as GSH, or a high molecular weight protein) that is subsequently reduced by a thiolate to regenerate the active selenol-selenolate group (Figure 3). The importance of these interactions for the toxicity and pharmacology of diphenyl diselenide will become clear in the next sections of this review.

\subsection{Molecular toxicology of diphenyl diselenide}

The toxicity of diphenyl diselenide and related compounds can be associated, at least in part, with their analogy to thiol-disulfide groups.(Scheme 1), ${ }^{6}$ which can bring about an exchange reaction. From the biological point of view, this exchange reaction diselenide-selenol/ thiol-disulfide can be considered a futile cycle that can lead to thiol depletion. In fact, the equilibrium of the reaction (Scheme 1) of a low molecular weight thiol (in the living cell environment the predominant thiol is glutathione) or of a high molecular weight thiol (sulfhydryl-containing enzymes or proteins) with diphenyl diselenide can be shifted to the right as a consequence of oxidation of the selenol by molecular oxygen (Scheme 2).

$2 \mathrm{R}^{1} \mathrm{SH}+\mathrm{R}^{2} \mathrm{SeSeR}{ }^{2} \rightleftharpoons 2 \mathrm{R}^{2} \mathrm{SeH}+\mathrm{R}^{1} \mathrm{SSR}^{1}$

Scheme 1.

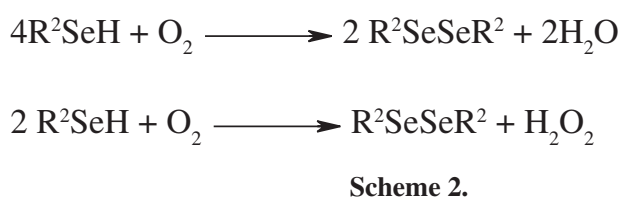

The steocheometry of this reaction is complex and, theoretically, four equivalents of selenol could reduce oxygen to water (Scheme 2a) or 2 equivalents of selenol could form a hydrogen peroxide molecule (Scheme $2 b$ ).

The interaction of different aryl diselenides with lowmolecular weight thiols and with the thiol-containing mammalian $\delta$-aminolevulinate dehydratase $(\delta$-ALA-D) have been demonstrated by different laboratories. ${ }^{6,10-12}$

We have demonstrated that the inhibition of mammalian $\delta$-ALA-D by diphenyl diselenide was dependent on the oxidation of cysteinyl residues located in the active site of the enzyme and that in an anaerobic environment the oxidation and inhibition of $\delta$-ALA-D by diphenyl diselenide was markedly decreased..$^{10,12}$ These results support the view that the catalytic oxidation of thiols by diphenyl diselenide (and analogs) depends on the instability of the selenol-selenolate in an aerobic environment, i.e., molecular oxygen can oxidized back the selenol groups to a diselenide. Further support to this mechanism of
$\delta$-ALA-D inhibition by diphenyl diselenide was obtained using sodium borohydride, diphenyl diselenide and purified bovine $\delta$-ALA-D in an anaerobic environment. ${ }^{12}$ In these set of experiments, we have observed an activation of $\delta$-ALA-D, instead of an inhibition, which have strongly suggested that the formation of a stable selenol in an anaerobic environment can reactivated the bovine $\delta$-ALA-D even more than a reduced thiol. ${ }^{12}$ The stronger selenolsenelonate reducing potency over than that of an analog thiol-thiolate is anticipated, because selenolate is a more powerful nucleophile than a thiolate analog. Furthermore, at a physiologic $\mathrm{pH}$, the concentration of the actual nucleophile, i.e. the selenolate or the thiolate, is supposed to be 2 to 3 order higher for the selenol than for the analog thiol (Figure 2).

If reaction 1 (Scheme 1) takes place in an aerobic environment (as it is the environment of mammalian cells), the net result can be the complete oxidation of the thiols (from GSH or thiol-containing enzymes) and this can be produced by a catalytic amount of diselenide. Thus, the oxidation of thiol by diselenide, in addition to deplete the thiol status of the cell, can also produce pro-oxidant forms (such as hydrogen peroxide) during selenol oxidation back to diselenide (Scheme 2b).

We have also observed that the low molecular weight dithiol, dithiothreitol (DTT), is a better substrate for the pro-oxidant catalytic effect of diphenyl diselenide than GSH. ${ }^{10,11,13}$ Indeed, the interaction of diphenyl diselenide with insect, fish and mammalian $\delta$-ALA-D and other thiolcontaining enzymes or proteins, such as $\mathrm{Na}^{+}, \mathrm{K}^{+}$-ATPase and vicinal mitochondrial thiol containing proteins, can be facilitated by the proximity or by the presence of vicinal thiol groups in their tertiary structure (Figure 4). ${ }^{13-15}$ Taken together, these in vitro results can indicate that high molecular weight containing-molecules, i.e., specific classes of proteins or enzymes can be preferential targets of diphenyl diselenide and analogs than GSH.

In summary, the molecular toxicity of diselenide compounds can be associated with catatlytic oxidation of endogenous or physiologically important thiol groups from GSH or from different proteins or enzymes. In the case of enzymes, the oxidation of thiols by diselenide compounds can inhibit enzyme activity, which can contribute to cellular toxicity. ${ }^{15}$ Consequently, the sum of reactions 1 and 2 (Schemes 1 and 2), can be considered the potential toxic pathway for the interaction of diselenide compounds with endogenous thiols. In fact, the final products of these reactions are diselenide and, possibly, hydrogen peroxide or water (the contribution of reaction $2 \mathrm{a}$ or $2 \mathrm{~b}$, Scheme 2, during the selenol oxidation is unknown). Most important here is that molecular oxygen 


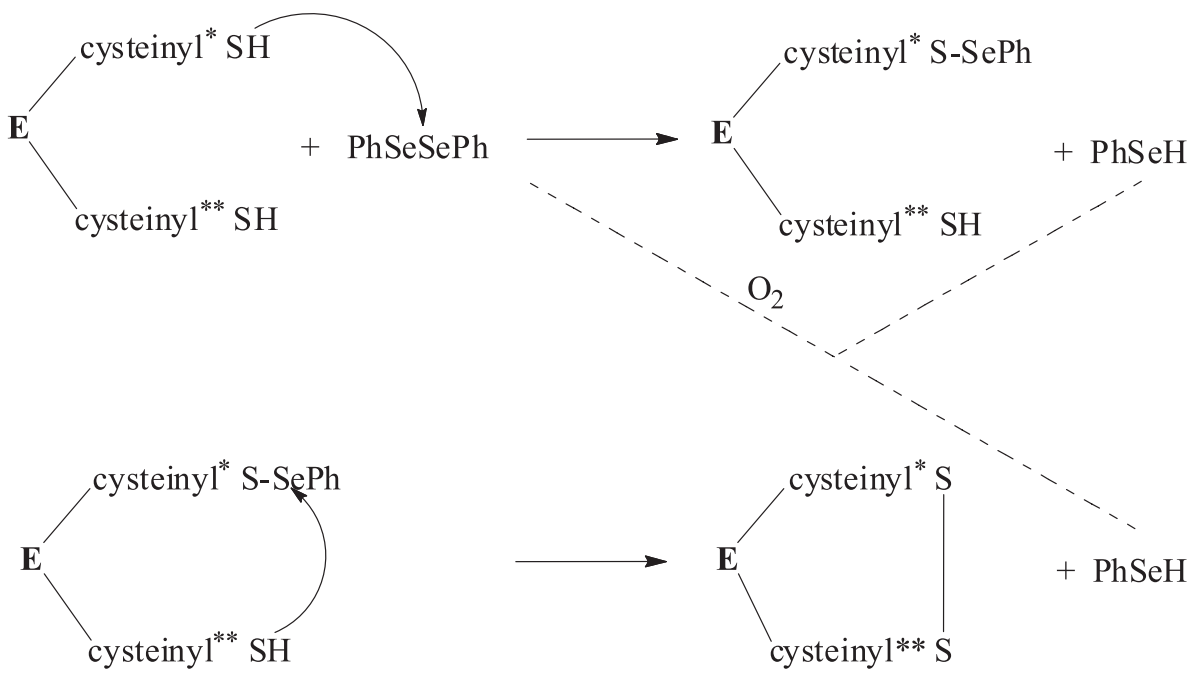

Figure 4. Oxidation of thiol-containing enzymes by diphenyl deselenide ( $\mathrm{PhSeSePh})$. In this scheme, the formation of disulfide in the active center of the enzyme occurs at two steps. First, a more reactive cysteinyl residue (labeled with one *) interacts with diphenyl deselenide, forming a selenol $(\mathrm{PhSeH})$. As a consequence of the proximity of the thiol groups, the second step is facilitated. The cysteinyl less reactive (labeled with $* *$ ) attacks the S-Se bond, releasing the second selenol. The dashed lines indicate the oxidation of selenol groups back to diselenide. Adapted from Farina and co-workers. ${ }^{14}$

destabilizes selenol-selenolate intermediates, oxidizing them back to diselenides. The importance of formation of a stable selenol-selonate intermediate for the potential pharmacologic or antioxidant activity of diselenide will be discussed in the next section.

\subsection{Molecular pharmacology of diphenyl diselenide}

As indicated in Scheme 1, the interaction of thiol groups with diselenides can generate intermediate selenol groups. In a similar way to that occurs in the active center of selenogluthathione peroxidase isoforms, the selenol-selenolate group formed can decompose hydrogen peroxide and lipid peroxides (compare Figure 3 with Figures 5 and 6).

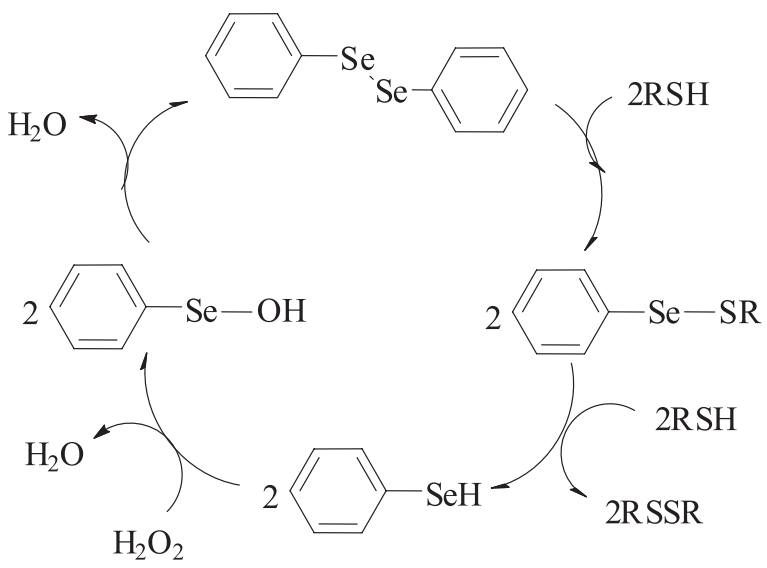

Figure 5. The thiol peroxidase-like cycle of diphenyl diselenide.

Consequently, the selenol formed after interaction of diselenide groups with thiol-thiolates can behave and catalyze peroxide degradation in a GPx-like manner. ${ }^{6}$ Indeed, as discussed briefly above, the pharmacological properties of ebselen and diphenyl diselenide can be associated with their antioxidant activities that greatly rely in the formation of a selenol group after interaction with reducing thiols. ${ }^{6}$

The thiol peroxidase-like activity of diphenyl diselenide and analogs can be easily demonstrated in pure in vitro chemical models. ${ }^{6}$ However, the occurrence of such type of reaction after in vivo administration or even in vitro using simple biological systems is difficult to determine. In fact, we have observed that spontaneous or induced $\left(\mathrm{Fe}^{2+}, \mathrm{Cu}^{2+}, \mathrm{pH}\right.$, sodium nitropruside, oxalate, quinolinic acid, etc) lipid peroxidation in brain, liver, kidney homogenates or human plasma LDL can be decreased by diphenyl diselenide. ${ }^{16}$

Similarly in a more preserved in vitro system (i.e., using $0.4 \mathrm{~mm}$ slices which conserve the cellular structure of the tissue), diphenyl diselenide protected brain slices from the pro-oxidant effect of hydrogen peroxide and its potency as antioxidant was increased one to two orders of magnitude by the inclusion of exogenous thiols in the system. ${ }^{17}$ Similarly, the in vitro pro-oxidant activity of the environmental neuroxicant methylmercury ${ }^{18}$ in brain cortical slices was blocked by diphenyl diselenide ${ }^{19}$ and ebselen tentatively via degradation of hydrogen peroxide formed at the mitochondrial level. ${ }^{18,19}$ The results obtained with brain slices clearly indicated that diphenyl diselenide can behave as a mimetic of GPx in biological systems in vitro. Furthermore, these results may suggest that the blockage of lipid peroxidation by diphenyl diselenide observed under different experimental 
situations can be related to the decomposition of lipid peroxides formed during the propagation phase of lipid peroxidation (Figure 6). However, one aspect that must be proven experimentally is the formation of selenol intermediate from diphenyl diselenide after incubation with tissue homogenates. Although tissue homogenates contain both non-protein thiol groups (NPSH) and protein-thiol groups, we do not know whether their concentrations are sufficient to maintain adequate level of selenol-selenolate intermediates for decomposition of fatty acid hydroperoxides or even their peroxyl radicals (Figure 6).

One experimental data that indirectly indicates that diphenyl diselenide must be reduced to its selenol-selenolate form to inhibit lipid peroxidation is the ineffectiveness of diphenyl diselenide as an inhibitor of Fenton reaction. Indeed, we have observed that, in the absence of any added thiol or other reducing agent, diphenyl diselenide does not inhibit dessoxyribose degradation stimulated by $\mathrm{Fe}^{2+}$ and ascorbate (unpublished results).

\section{In Vivo Biochemistry}

\subsection{General toxicity}

Selenium compounds are considered "Janus compounds", i.e., products with a double face, because of their contrasting behavior that is dose dependent. At low doses, organoselenium has beneficial effects, whereas high doses are toxic. The threshold dose for these opposing properties has not yet been established.

Regarding the toxicity of organoselenium selenium compounds, diphenyl diselenide was less toxic than ebselen in rats acutely treated by the intraperitoneal route as compared to the lethal dose $\left(\mathrm{LD}_{50}\right)$ for ebselen $\left(400 \mu \mathrm{mol} \mathrm{kg}^{-1}\right)^{20}$ and for diphenyl diselenide $\left(1200 \mu \mathrm{mol} \mathrm{kg}{ }^{-1}\right) .{ }^{21}$ Ebselen has been used as a reference compound in view of its low toxicity and its use in human trials. ${ }^{4}$ Ebselen has been reported as a non toxic organoselenium compound because the non bioavailability of free selenium from its molecule. The lack of incorporation of $\left({ }^{75} \mathrm{Se}\right)$ into hepatic

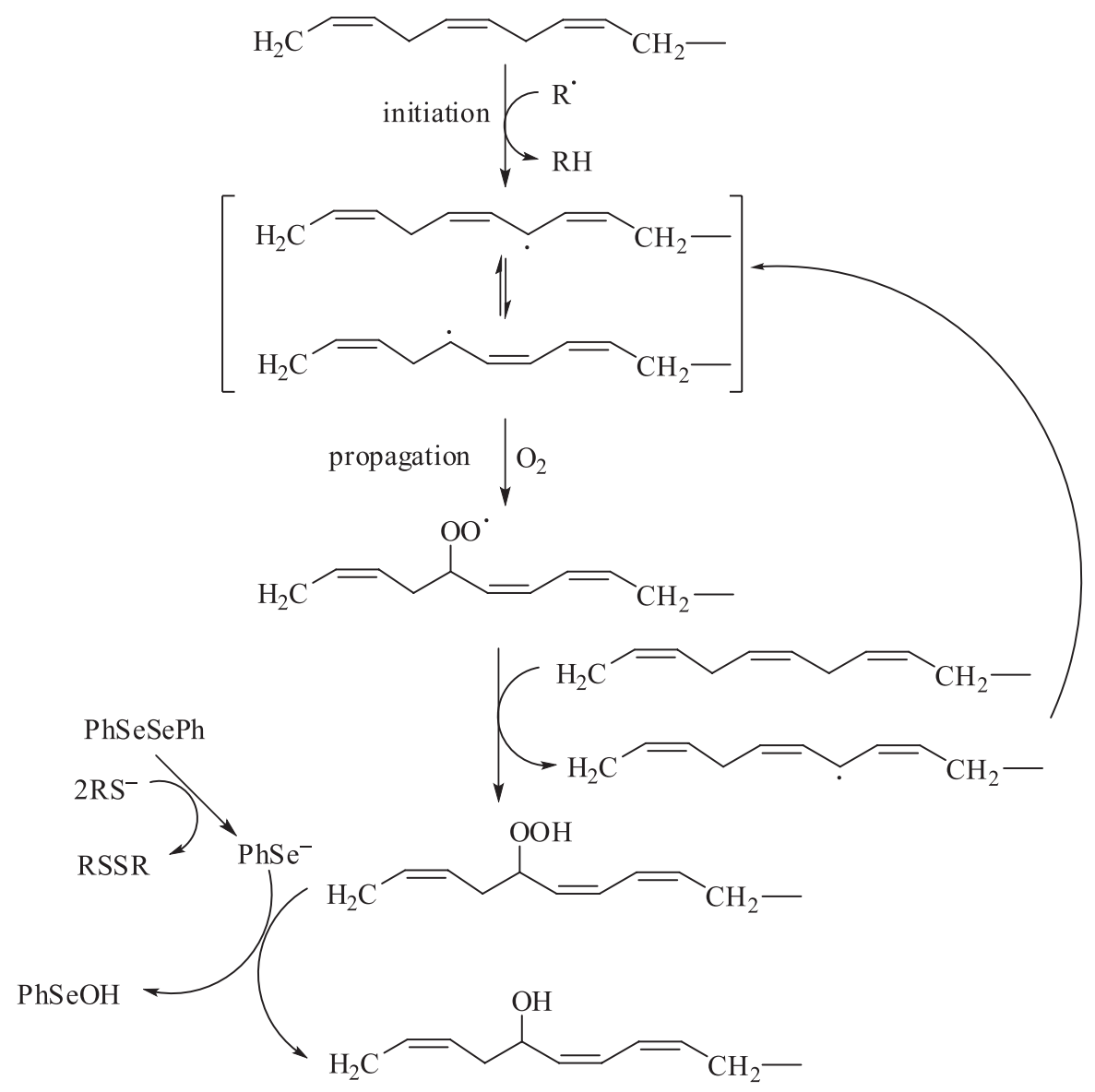

Figure 6. Inhibition of lipid peroxidation by the selenol-selenolate formed after reduction of diphenyl diselenide $(\mathrm{PhSeSePh})$ by endogenous thiols. $\mathrm{R} \cdot$ can be a variety of different endogenous generated free radicals, such as $\mathrm{HO} \cdot \mathrm{LO} \cdot($ radical generated from a lipid peroxide by Fenton's reaction), peroxyl radical (LOO; similar to this one depicted in this figure), NO;, etc. Diphenyl diselenide can block lipid peroxidation via its reduction to selenol-selenolate, which can decompose lipid peroxide to form a chemically inert alcohol. 
glutathione peroxidase $48 \mathrm{~h}$ after administration to mice of $6 \mu \mathrm{Ci}\left({ }^{75} \mathrm{Se}\right)$-labeled ebselen further supports this idea. ${ }^{22}$

With regard to animal species, diphenyl diselenide was more toxic in mice than rats when administered by the intraperitoneal route $\left(\mathrm{LD}_{50} 210\right.$ and $1200 \mu \mathrm{mol} \mathrm{kg} \mathrm{k}^{-1}$, respectively) and had no acute lethal toxic effects when administrated by the subcutaneous ${ }^{20,21}$ or oral ${ }^{23}$ route. While, ebselen presented similar acute lethal potency in rats and mice when administrated by the intraperitoneal route $\left(\mathrm{LD}_{50}\right.$ values of 400 and $340 \mu \mathrm{mol} \mathrm{kg}{ }^{-1}$, respectively). ${ }^{20}$

The crucial importance of the administration route for the diphenyl diselenide toxicity was demonstrated by Savegnago et al.${ }^{24}$ Calculated $\mathrm{LD}_{50}$ for diphenyl diselenide administered by the oral route to mice was estimated to be $>1 \mu \mathrm{mol} \mathrm{kg}{ }^{-1}$. Therefore, diphenyl diselenide was less toxic to mice when administered by the oral or subcutaneous route than by the intraperitoneal route.

To study the influence of chemical structure in the diaryl diselenide toxicity, oral acute toxicity of disubstituted diaryl diselenides was evaluated in mice. ${ }^{23}$ As can be seen in Table 1, the $\mathrm{LD}_{50}$ values for disubstituted diaryl diselenides were very similar to that found for diphenyl diselenide.

Table 1. Lethal dose $\left(\mathrm{LD}_{50}\right)$ for a single acute oral administration of diphenyl diselenide $(\mathrm{PhSe})_{2}$ and its analogs in mice

\begin{tabular}{ll}
\hline Compound & Dose $\left(\mathrm{mmol} \mathrm{kg}^{-1}\right)$ \\
\hline$(\mathrm{PhSe})_{2}$ & $>1\left(312 \mathrm{mg} \mathrm{kg}^{-1}\right)$ \\
$\left(p-\mathrm{Cl}_{-} \mathrm{C}_{6} \mathrm{H}_{4} \mathrm{Se}\right)_{2}$ & $>1\left(381 \mathrm{mg} \mathrm{kg}^{-1}\right)$ \\
$\left(m-\mathrm{CF}_{3}-\mathrm{C}_{6} \mathrm{H}_{4} \mathrm{Se}\right)_{2}$ & $>0.62\left(278 \mathrm{mg} \mathrm{kg}^{-1}\right)$ \\
$p-\left(\mathrm{CH}_{3} \mathrm{O}-\mathrm{C}_{6} \mathrm{H}_{4} \mathrm{Se}\right)_{2}$ & $>1\left(372 \mathrm{mg} \mathrm{kg}^{-1}\right)$ \\
\hline
\end{tabular}

Therefore, we have demonstrated that the introduction of functional groups into the aryl group of diaryl diselenide did not introduce pronounced changes in toxicity. ${ }^{25}$ On the other hand, there was an increase in toxicity when $\left(m-\mathrm{CF}_{3}-\mathrm{C}_{6} \mathrm{H}_{4} \mathrm{Se}\right)_{2}$ was administered by oral route in rats (compare $\mathrm{LD}_{50}$ values for $\left(m-\mathrm{CF}_{3}-\mathrm{C}_{6} \mathrm{H}_{4} \mathrm{Se}\right)_{2}$ and diphenyl diselenide $\left(0.523 \mu \mathrm{mol} \mathrm{kg}{ }^{-1}\right.$ and $>1 \mu \mathrm{mol} \mathrm{kg}{ }^{-1}$, respectively $){ }^{23}$

One important set of evidence which supports the brain as a potential target for the toxicity of highly lipophilic organoselenium compounds and possibly for their pharmacological and therapeutic actions are the demonstration that diphenyl diselenide crosses the bloodbrain barrier and the increase in brain selenium levels in mice after acute and chronic exposure to diphenyl diselenide. ${ }^{26}$ Additionally, strong evidence has been accumulated indicating that diphenyl diselenide presents convulsant activity. ${ }^{27}$ The appearance of seizures and the plasmatic level of diphenyl diselenide are dependent on the administration route (i.p. > p.o. > s.c.), the vehicle solution (DMSO > canola oil) and animal species (mice $>$ rats). After oral administration of $500 \mathrm{mg} \mathrm{kg}^{-1}$, rat and mouse peak plasma diphenyl diselenide levels were 13.13 and $10.11 \mu \mathrm{g} \mathrm{mL}^{-1}$ $\left(\mathrm{C}_{\max }\right)$, respectively, and occurred at $0.5 \mathrm{~h}\left(\mathrm{~T}_{\max }\right)$ post-dosing. ${ }^{28}$ Moreover, diphenyl diselenide has been demonstrated to affect a number of neuronal processes. ${ }^{29}$

All new drug applications include data from animal developmental and reproductive-toxicology studies. Considering diphenyl diselenide a possible new drug candidate, reproductive and teratogenic studies with diphenyl diselenide in rats have been performed. ${ }^{30}$ Maternal subcutaneous injection of diphenyl diselenide led to an increased incidence of skeletal variations in rat fetuses ${ }^{30}$ and adverse effects on embryo-fetal development. ${ }^{31}$ The effect of lactational exposure to diphenyl diselenide on developmental and behavioral parameters in rats was also demonstrated. $^{32}$

Regarding the effect on male reproductive health, diphenyl diselenide administered neither intraperitoneally (acute treatment) nor subcutaneously (subchronic treatment) to adult male rats caused reproductive toxicity. ${ }^{33}$

\subsection{Interaction with thiols}

As described in the beginning of this review, organoselenium compounds can react with thiols to produce disulfides in vitro and this type of interaction can be responsible for their in vivo toxicity. However, the in vivo effects of diphenyl diselenide on low and high-molecular weight thiols depend greatly on the administered dose and on the considered thiol target.

\subsubsection{Paradoxal effects on low-molecular weight endogenous thiols}

Concerning organoselenium action on the cellular redox state, our present knowledge is rather controversial and it seems to depend on not only the chemical form and the element consumed, but also on a variety of other factors including species, age, physiological state, nutrition and dietary interactions, and the route of administration ${ }^{6}$ that can evoke either pro-oxidative or antioxidative effect.

\subsubsection{Decrease of low-molecular weight thiol levels}

A remarkable feature of organoselenium compounds consists of their ability to oxidize thiols to disulfide under reducing conditions. In this context, evidence has been accumulated indicating that the pro-oxidative effect of diphenyl diselenide is related to its toxicity in mammals.

As reported above GSH is the dominant NPSH in mammalian cells; as such it is essential in maintaining the intracellular redox balance and the essential thiol status 
of proteins. ${ }^{34}$ GSH undergoes thiol-disulfide exchange in a reaction catalyzed by thiol-transferase as showed in Scheme 3.

$$
\text { Protein-SSG + GSH } \rightleftharpoons \text { Protein-SH + GSSG }
$$

Scheme 3.

Since this is a reversible reaction, the equilibrium is determined by the redox state of the cell, which depends on the concentrations of GSH and GSSG. ${ }^{35}$ Given that diphenyl diselenide decreases GSH content, the cellular GSSG content could increase. As a consequence the thioldisulfide equilibrium within the cell could be altered as well as a diverse number of metabolic processes including enzyme activity, transport activity, signal transduction, and gene expression via alteration of redox sensitive transcription factors. Furthermore, as discussed early, diphenyl diselenide can oxidize more dithiol containing molecules (including here high weight molecular proteins containing vicinal thiol groups) than monothiols, which can convert enzymes or proteins with vicinal thiol groups primary targets for diselenides. Accordingly, acute or sub-acute exposure to diphenyl diselenide caused a more marked decrease in hepatic or cerebral $\delta$-ALA-D activity than in NPSH levels. ${ }^{11}$

Considering the importance of GSH content in maintaining the intracellular redox balance, we have investigated the effect of diphenyl diselenide on this low molecular weight endogenous thiol in different tissues of rodents. A single subcutaneous administration of diphenyl diselenide decreased the plasmatic levels of NPSH in mice. ${ }^{36}$ In a sub-acute protocol, mice exposed for 14 days to diphenyl diselenide, presented a significant reduction in liver NPSH content. ${ }^{11}$

Rosa and co-workers ${ }^{37}$ have demonstrated that a single exposure with diphenyl diselenide significantly reduced the concentration of reduced form of intracellular glutathione but did not increase that of the oxidized form GSSG. Apparently, high doses of diphenyl diselenide administered by intraperitoneal route depleted GSH in mice organs and tissues, therefore increasing the ratio GSSG/GSH. Taken together these results indicate that diphenyl diselenide, administered at high doses by either intraperitoneal or subcutaneous route, reacts with NPSH depleting NPSH content in different tissues of mice.

The property of diphenyl diselenide to oxidize thiols has been also demonstrated in the presence of other xenobiotics. In both reported studies the effect of paracetamol and lead acetate varied depending on the organoselenium treatment. On the one hand, diphenyl diselenide further decreased NPSH after treatment with paracetamol, whereas ebselen, a relatively safe organoselenium compound, did not modify the effect of this xenobiotic on NPSH content in liver of rats. ${ }^{38}$ On the other hand, treatment of mice with lead acetate, ebselen or diphenyl diselenide did not change the levels of NPSH in liver. While simultaneous exposure of mice to lead acetate and ebselen reduced hepatic NPSH levels, the combination of diphenyl diselenide and lead acetate did not alter NPSH content. ${ }^{39}$

\subsubsection{Increase of low-molecular weight thiol levels}

Different groups of research around the world have suggested that the antioxidant activity of organoselenium compounds is, at least in part, due to an induction in GSHrelated antioxidant capacity. In general, it is a consensus that while it is relatively easy to increase GSH levels by administering various GSH or cysteine precursor agents when GSH levels have been depleted by prior treatment with a GSH depleting agent, it has proven much more difficult to enhance GSH content to levels above what is considered normal. ${ }^{40}$

Accordingly, the induction in NPSH-related antioxidant capacity by diphenyl diselenide was demonstrated by our research group. In a series of different experimental protocols, diphenyl diselenide has been proved to increase NPSH levels in erythrocytes, lungs, liver, kidney and brain of adult and young rats. ${ }^{41}$

Since diphenyl diselenide action on low molecular endogenous thiol depends on a variety of factors including species, this organoselenium compound was investigated in different species. Diphenyl diselenide was able to increase NPSH levels in erythrocytes of rabbits ${ }^{42}$ and in different tissues of mice. ${ }^{43}$

\subsubsection{Inhibition of $\delta$-ALA-D activity following exposure to diphenyl diselenide}

As addressed in the part I of this review, the mechanism by which diphenyl diselenide causes toxicity to rodents is related to the inhibition of thiol-containing enzymes among them $\delta$-ALA-D.

In 2000, it was reported the first evidence that diphenyl diselenide is an inhibitor of $\delta$-ALA-D activity in mice. ${ }^{11}$ The inhibition of $\delta$-ALA-D activity by diphenyl diselenide has been reported to be dependent on the time of exposure (acute or sub-acute), dose and tissue. In this way, acute or sub-acute administration of diphenyl diselenide inhibited erythrocytic, hepatic and cerebral $\delta$-ALA-D activities in mice. The inhibition of $\delta$-ALA-D activity may contribute to the impairment of heme biosynthesis and possibly to a deregulation of metabolic pathways dependent on hemecontaining enzymes. ${ }^{20,26,44}$ Similarly, diphenyl diselenide significantly inhibited cerebral, hepatic and renal $\delta$-ALA-D 
activity in rats, suggesting that the inhibitory effect is not species-dependent for rodents. ${ }^{27,45}$ However, in contrast with the results obtained with mice the inhibition in $\delta$-ALA-D activity neither impact in hematocrit nor in hemoglobin concentration. ${ }^{46}$

The potential inhibitory effect of diphenyl diselenide on $\delta$-ALA-D activity was investigated in rabbits as well. Different from the previous results demonstrated in mice and rats, the intake of diphenyl diselenide increased hepatic and cerebral cortical $\delta$-ALA-D activities in blood, liver and brain of rabbits. However, acute intraperitoneal administration of diphenyl diselenide to rabbits did not modify $\delta$-ALA-D from kidney, liver, muscle, cerebellum and brain cortex. Hippocampal $\delta$-ALA-D activity was decreased, whereas cardiac enzyme activity was slightly increased in rabbits acutely exposed to diphenyl diselenide. ${ }^{42,47}$

The reasons for the differences found in the rabbit studies if compared to the studies on mice and rats are at present unknown but are most likely related to the long-term exposure, the route of administration and species.

\subsubsection{Functional consequences of $\delta$-ALA-D inhibition}

As reported above diphenyl diselenide is a potent inhibitor of $\delta$-ALA-D activity in different tissues of rodents. Diphenyl diselenide oxidizes sulfhydryl groups of the active site of $\delta$-ALA-D, changing the configuration of the enzyme and impairing its activity. ${ }^{6}$ Indeed, the impairment of $\delta$-ALA-D functionality may impair heme biosynthesis and result in the accumulation of $\delta$-aminolevulinic acid (ALA).
Bechara and co-workers ${ }^{48}$ have reported that the accumulation of ALA affects the aerobic metabolism and has some pro-oxidant activity. In this context, we assume that the toxicological effects caused by diphenyl diselenide probably involve the accumulation of ALA, which produces reactive oxygen species, and the impairment of heme biosynthesis pathway as a consequence of $\delta$-ALA-D inhibition (Figure 7).

ALA oxidation has been shown to be particularly damaging in the brain of rats treated with this molecule. Therefore, the data reported on ALA neurotoxicity ${ }^{49}$ lead us to speculate that same of the neurotoxic effects caused by high doses of diphenyl diselenide in rodents are associated to $\delta$-ALA-D inactivation and consequent accumulation of ALA.

\subsection{Interaction with heavy metals}

\subsubsection{Mercury}

Mercury can be found in the environment in different chemical forms and all of them are potentially toxic. $\mathrm{Hg}^{2+}$ and methylmercury $(\mathrm{MeHg})$ are the two most important forms of mercury found in the environment ${ }^{7,18}$ and chemically they can be classified as soft acids (soft electrophiles) and will react preferentially with soft bases (soft nucleophiles).$^{50}$ In living cells, the most important nucleophile center is the sulfhydryl group (thiol/thiolate; Figure 2) found in proteins and GSH. Similarly, as discussed early, selenohydryl group (selenol/selenolate;

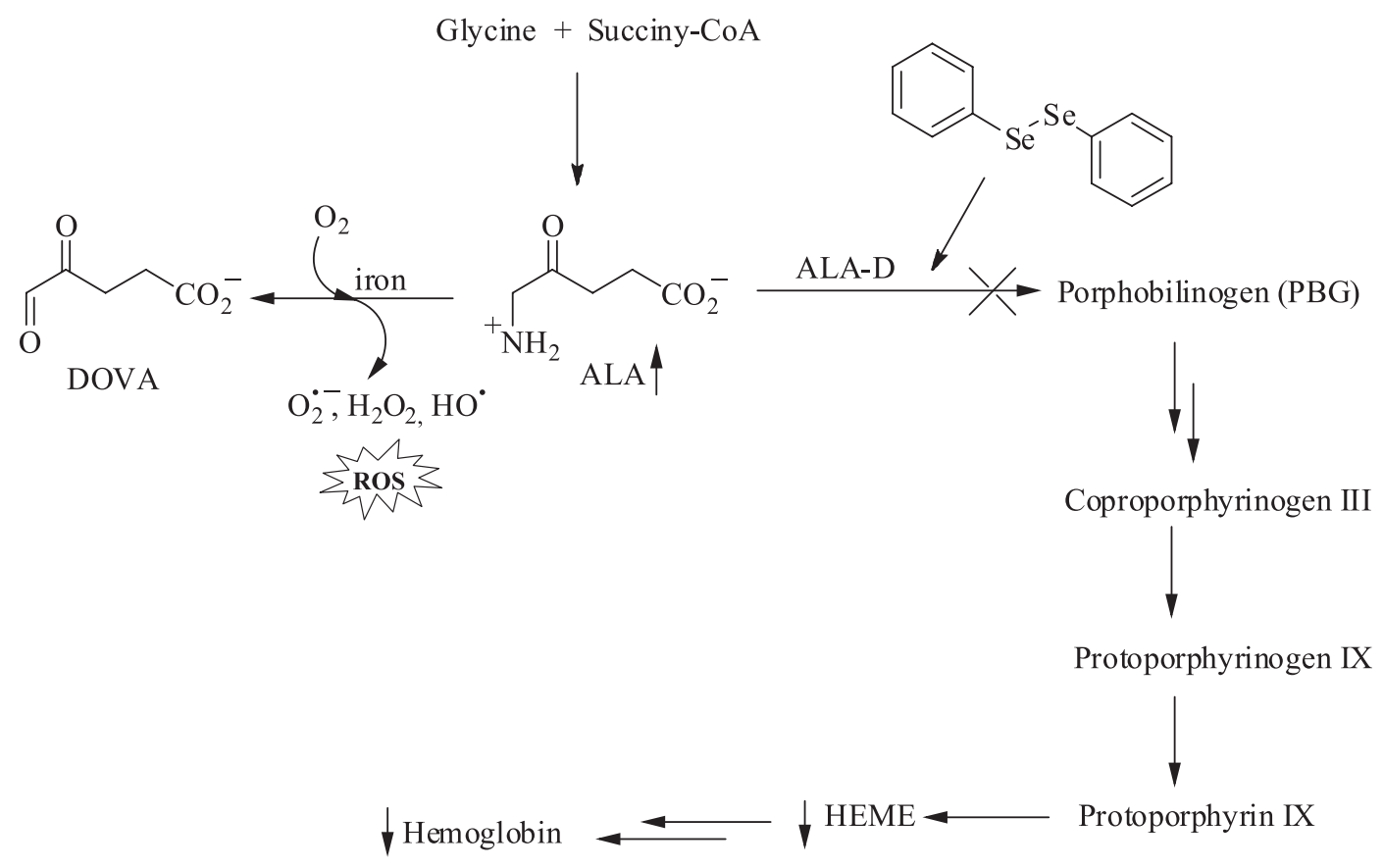

Figure 7. Inhibition of $\delta$-ALA-D activity by diphenyl diselenide leading to 5 -aminolevulinic acid (ALA) overload, reduction of the heme group biosynthesis and increase in reactive oxygen species (ROS) production. 
Figure 2) is one of the strongest nucleophile center found in selenoproteins. Of particular importance for the toxicity of mercurial, selenol groups have higher affinity for mercury than thiols, which is related to the size of the selenium atom (i.e., its softness) as compared to that of the sulfur atom. ${ }^{51}$ In fact, the selenol and thiol groups can react with mercurial according to Scheme 4, depending on the chemical form of mercury.

$$
\begin{gathered}
\mathrm{RXH}+\mathrm{CH}_{3} \mathrm{Hg}^{+} \longrightarrow \mathrm{RXHgCH}_{3} \text { or } \\
2 \mathrm{RXH}+\mathrm{Hg}^{2+} \longrightarrow \mathrm{RXHgXR} \\
\text { Scheme 4. }
\end{gathered}
$$

Consequently, the toxicity of mercurials can be modified by their interaction with thiol or selenol group and in view of the fact that diphenyl diselenide can be reduced to its selenol intermediate after interaction with thiols, we have demonstrated that diphenyl diselenide could change the toxicity of mercurials after in vivo exposure.

Exposure to $\mathrm{HgCl}_{2}$ and diphenyl diselenide thirty minutes after the last injection of $\mathrm{HgCl}_{2}$ caused mortality in $100 \%$ of mice, suggesting a toxic synergist effect between $\mathrm{Hg}^{2+}$ and selenium. Since exposure to $\mathrm{HgCl}_{2}$ or diphenyl diselenide caused neither renal nor hepatic toxicity, we infer that toxicity observed in mice exposed to $\mathrm{HgCl}_{2}$ and diphenyl diselenide is related to a complex formed between $\mathrm{Hg}^{2+}$ and diphenyl diselenide which could have pro-oxidant activity (Scheme 5). ${ }^{36}$<smiles></smiles>

Scheme 5.

Keeping in mind the dual effects of selenium against $\mathrm{Hg}^{2+}$ toxicity, a one week pretreatment protocol with diphenyl diselenide was investigated against hematological and immunological alterations caused by $\mathrm{HgCl}_{2}$ in mice. The pretreatment with diphenyl diselenide was effective in protecting against the immunological and hematological alterations induced by $\mathrm{HgCl}_{2}$ in mice. ${ }^{52}$

Following a very similar protocol, the effect of combined therapy with diphenyl diselenide and 2,3-dimercaptopropane-1-sulfonic acid (DMPS) was investigated against toxicity induced by $\mathrm{HgCl}_{2}$ in mice. The results proved that combined therapy with diphenyl diselenide and DMPS was less effective than isolated therapies to counteract renal and hematological damage induced by $\mathrm{HgCl}_{2}$ in mice. Therefore, one can propose that ligand competition between diphenyl diselenide and $\mathrm{Hg}^{2+}$ to complex with DMPS gives preferentially the DMPS-SePh complex (Scheme 6). As a consequence of preferential thiol group attack to diphenyl diselenide to give two new Se-S bounds, the DMPS- $\mathrm{Hg}^{2+}$ complex is less probable to occur, reducing urinary excretion of $\mathrm{Hg}^{2+}$ and the effectiveness of DMPS. ${ }^{53}$<smiles>O=S(=O)(O)CC1CSCC([SeH])SC1</smiles>

Scheme 6.

Regarding the interaction of diphenyl diselenide with $\mathrm{MeHg}$, we have recently demonstrated that simultaneous exposure to these compounds caused a marked decrease in the deposition of mercury in liver, kidney and brain of mice. We have proposed that the selenol intermediate formed after reduction of diphenyl diselenide could react with $\mathrm{MeHg}$ to form a more excretable complex of the type $\mathrm{CH}_{3} \mathrm{HgSePh}$, which considerably reduced the $\mathrm{Hg}$ burden in adult mice. ${ }^{54}$ The potential formation of stable complex(es) between selenolate intermediate after reduction of ebselen by endogenous thiols could help to explain the protective effect of ebselen administration in different regimen of $\mathrm{MeHg}$ exposure in rats and mice. ${ }^{55}$ In view of the reduction of mercury deposition after simultaneous exposure to diphenyl diselenide and protective effects of ebselen against $\mathrm{MeHg}$, we suppose that selenolate intermediates (formed after the reaction of these organoselenium compounds with endogenous thiols) could increase the excretion of mercury. The question that remains unsolved here is whether diphenyl diselenide or ebselen could remove previously deposited mercury.

\subsubsection{Cadmium}

Studies show that supplementation of antioxidants along-with a chelating agent prove to be a better treatment regimen than monotherapy with chelating agents. ${ }^{56}$ Thus, it is believed that antioxidant should be one of the important components of an effective treatment of $\mathrm{Cd}$ poisoning. The use of combined therapy meso 2,3-dimercaptosuccinic acid (DMSA) and diphenyl diselenide did not prove to be better than the monotherapy in improving toxicological parameters altered in $\mathrm{Cd}$-induced testicular damage in mice. ${ }^{57}$ Conversely, the use of combined therapy with DMPS and diphenyl diselenide proved to be efficient in decreasing $\mathrm{Cd}^{2+}$ levels in testes and in ameliorating damage induced by this metal. ${ }^{58}$ Ascorbic acid and non-protein 
sulfhydryls, non-enzymatic antioxidant defenses, are involved in the diphenyl diselenide action against toxicity caused by $\mathrm{CdCl}_{2}$ in testes of mice. ${ }^{43}$

We have extended our studies and reported that the administration of the antioxidant, diphenyl diselenide, may provide beneficial effects by reducing oxidative stress in different tissues of rodents sub-chronically exposed to $\mathrm{CdCl}_{2} \cdot{ }^{59}$ Conversely, $\mathrm{CdCl}_{2}$ and diphenyl diselenide caused a nocive effect in testes of mice. Progressive damage and histopathological changes in the testis were not ameliorated with, but rather were potentiated by, diphenyl diselenide therapy. ${ }^{60}$ Taken together these results indicate that $\mathrm{CdCl}_{2}$ and diphenyl diselenide interaction depends on the tissue and regimen of dosage evaluated. In fact, diphenyl diselenide ameliorated toxicity induced by $\mathrm{CdCl}_{2}$ in liver, brain and spleen while potentiated in testes of mice. Regarding the regimen of dosage, acute and subchronic protocols showed antagonic effects of diphenyl diselenide on $\mathrm{CdCl}_{2}$-induced injury in testes of mice. In an acute protocol diphenyl diselenide protected against injury induced by $\mathrm{CdCl}_{2}$ in testes while in a sub-chronic exposure the effect was potentiated. It is also important to emphasize that the doses of diphenyl diselenide used in these studies were different.

The dual effects caused by subcutaneous administration of diphenyl diselenide on toxicity induced by $\mathrm{CdCl}_{2}$ in mice prompted us to design new experiments in which diphenyl diselenide was administered by oral route in rats. In a sub-chronic protocol, diphenyl diselenide has been reported to reduce hepatotoxicity caused by $\mathrm{CdCl}_{2} \cdot{ }^{61}$ The effectiveness of diphenyl diselenide in reducing cadmium concentration in liver ${ }^{61}$ and lungs of mice was also demonstrated. ${ }^{62}$

Taken together, $\mathrm{Hg}^{2+}$ and $\mathrm{Cd}^{2+}$ results enable us to draw some conclusions about the interaction between diphenyl diselenide and heavy metals, i.e., the therapeutic or toxic effect of diphenyl diselenide depends on the heavy metal and the dosage regimen. Based on chemical arguments, the complex formed between $\mathrm{Cd}^{2+}$ and diphenyl diselenide (Scheme 7) appears to be different from the Hg-diphenyl diselenide complex (Scheme 5). Accordingly, it has been reported that the reaction of diphenyl diselenide with mercurials afforded a strong Se-Hg covalent bond. On the other hand, the diphenyl diselenide and cadmium reaction gave a weak Se-Cd complexation. ${ }^{63}$ The results obtained in the in vivo system are in strict accordance

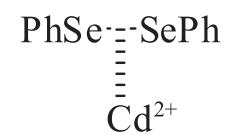

Scheme 7. with this argument, since diphenyl diselenide protected against toxicity of $\mathrm{Cd}^{2+}$ whereas the $\mathrm{Hg}$-diphenyl diselenide complex induced lethality in mice. ${ }^{36}$

\subsection{General pharmacology}

The fact that other groups ${ }^{4,64}$ around the world were investigating the pharmacological properties of organoselenium compounds associated with the fact that diphenyl diselenide causes toxicity only at high doses motivated us to explore this compound as a potential pharmacological agent. Pioneering work of our research group in 2003 showed that diphenyl diselenide has antiinflammatory and antinociceptive activities. In this study, we demonstrated for the first time that subcutaneous administration of diphenyl diselenide produced antiinflammatory activity superior than that of ebselen. It was also demonstrated for the first time the antinociceptive activity of ebselen. ${ }^{65}$

Since oral administration of drugs has some advantages including greater ease and convenience, diphenyl diselenide was screened for antinociceptive action after oral administration in mice. The main results of this study are presented in Table 2. It is clearly depicted in Table 2 that diphenyl diselenide was as effective at subcutaneous as at oral route for different chemical and thermal models of nociception in mice. ${ }^{65,66}$

Table 2. Effective doses of diphenyl diselenide $(\mathrm{PhSe})_{2}$ in different chemical and thermal models of nociception

\begin{tabular}{lcc}
\hline Test & \multicolumn{2}{c}{$(\mathrm{PhSe})_{2}{ }^{*}$} \\
\cline { 2 - 3 } & \multicolumn{2}{c}{ via } \\
\cline { 2 - 3 } & Subcutaneous & Oral \\
\hline Acetic Acid & 5 & 1 \\
Fomalin Phase I/II & $5 / 5$ & $0.1 / 0.5$ \\
Capsaicin & 10 & 1 \\
Tail immersion & 10 & 10 \\
\hline
\end{tabular}

*doses of $(\mathrm{PhSe})_{2}\left(\mathrm{mg} \mathrm{kg}^{-1}\right)$.

In an attempt to better understand the mechanisms by which diphenyl diselenide elicits the antinociceptive effect in the formalin test, mice were treated with different drugs. The antinociceptive effect of diphenyl diselenide in the second phase of the formalin test was prevented by intrathecal injection of $\mathrm{K}^{+}$channel blockers. ${ }^{66}$ Experimental results provide additional pharmacological evidence for the participation of $\mathrm{K}^{+}$channel as well as nitric oxide/cyclic, guanosine monophosphate $\left(\mathrm{GMP} / \mathrm{Ca}^{2+}\right.$ and serotonergic pathways in the antinociceptive effect of diphenyl diselenide. ${ }^{66,67}$ 
Moreover, diphenyl diselenide, administered orally, elicited a significant inhibition in the licking and the paw oedema caused by intraplantar injection of glutamate, bradykinin and phorbol myristate acetate (PMA) in mice. ${ }^{24}$

In view of the diphenyl diselenide effect in both phases of the formalin test (Table 2), we investigated if diphenyl diselenide has local antinociceptive activity as compared to ebselen. Diphenyl diselenide and ebselen produced a significant antinociceptive local effect on the late phase of the formalin test. ${ }^{67}$

The results obtained by Zasso ${ }^{67}$ with formalin are in better agreement with those in which local administration of diphenyl diselenide produced antinociceptive and antioedematogenic effects when co-injected with glutamate in mice. ${ }^{24}$ The involvement of redox regulatory site of glutamate receptors in antinociceptive action of diphenyl diselenide was demonstrated. ${ }^{24}$

Diphenyl diselenide elicits an anti-inflammatory effect when assessed in models of inflammation in rats, such as carragenin and arachidonic acid-induced paw oedema. ${ }^{65}$ Carragenin-induced inflammation in rat paw is mediated by a variety of agents, including vasoactive amines, bradykinin and arachidonic acid metabolites. ${ }^{68}$ Diphenyl diselenide inhibited arachidonic acid-induced edema, suggesting that this diselenide blocks the synthesis of mediators of inflammation.

Considering the reported findings on anti-inflammatory and antinociceptive action, diphenyl diselenide was proved to be a candidate for relieve of neuropathic and inflammatory pain as well as of acute thermal hyperalgesia. The results indicate that molecular mechanisms such as the inhibition of protein kinase $\mathrm{C}(\mathrm{PKC})$ and nitric oxide cell signaling and inflammatory mediators, such as prostaglandins, bradykinin, and excitatory aminoacids, $N$-methyl-D-aspartate, are involved in diphenyl diselenide effect. ${ }^{69}$

The evidence that the antinociceptive action of diphenyl diselenide depends on its selective interaction with $\mathrm{N}$-methyl-D-aspartate receptor was reinforced by the demonstration that diphenyl diselenide prevents glutamate and $N$-methyl-D-aspartate-induced biting response while did not alter the biting response caused by intrathecal injection of kainate, $\alpha$-amino-3-hydroxy-5-methyl-4isoxazolepropionic acid (AMPA) and 1-aminocyclopentanetrans-1,3-dicarboxylic acid ( $t$-ACPD). The interaction with vanilloid and peptidergic receptors as well as proinflammatory cytokines (bradykinin, interleukin $1 \beta$, tumor necrosis factor- $\alpha$ ) has been also reported. ${ }^{70}$

In an attempt to understand the mechanisms behind diphenyl diselenide antinociceptive action in a thermal model of nociception, we have planned a series of experiments in which diphenyl diselenide was evaluated in the hot-plate test. The data strongly suggest that the adenosine $A_{2 B}$ receptors could be involved in the antinociceptive effect caused by diphenyl diselenide in the mouse hot-plate. ${ }^{71}$

Besides antinociceptive and anti-inflammatory properties, during the last decade other biological activities of diphenyl diselenide have been reported and this compound has emerged as a candidate for different therapeutic purposes. As depicted in Table 3, diphenyl diselenide has been proven to be effective against different experimental models.

Table 3. Pharmacological effects of diphenyl diselenide on different experimental models

\begin{tabular}{|c|c|c|c|}
\hline Experimental model & Treatment & Animal species & Reference \\
\hline hepatotoxicity & acute & rat & Borges et al., ${ }^{72} 2005,2006$ \\
\hline gastric damage & acute & rat & Savegnago et al..$^{73} 2006$, Ineu et al. ${ }^{73} 2008$ \\
\hline pulmonary damage & acute & mice/rat & Luchese et al., $2007^{62}, 2009^{41}$ \\
\hline hyperglycemia & acute & rat & Barbosa et al..${ }^{41} 2006$ \\
\hline mammary carcinogenesis & chronic & rat & Barbosa et al..${ }^{74} 2008$ \\
\hline renal-failure & acute & rat & Brandão et al..$^{75} 2009$ \\
\hline anxiety-like & acute & mice & Savegnago et al. ${ }^{76} 2008$ \\
\hline \multirow[t]{2}{*}{ depressant-like } & acute & rat & Ghisleni et al..${ }^{77} 2008$ \\
\hline & acute & mice & Savegnago et al. ${ }^{76} 2008$ \\
\hline depressant-like caused by malathion & acute & rat & Acker et al. ${ }^{78} 2009$ \\
\hline cognitive performance & acute & mice & Rosa et al..${ }^{79} 2003$ \\
\hline spatial memory & sub-chronic & rat & Stangherlin et al.,$^{80} 2008$ \\
\hline orofacial dyskinesia & sub-chronic & rat & Burger et al. ${ }^{81} 2006$ \\
\hline hypercholesterolaemia & sub-chronic & rabbit & de Bem et al., ${ }^{82} 2009$ \\
\hline hyperlipidaemia & acute & mice & da Rocha et al. ${ }^{83} 2009$ \\
\hline
\end{tabular}




\subsubsection{Disubstituted diselenides}

The first study reporting the pharmacological property of disubstituted diaryl diselenides was published in 2003. In this study, the intraperitoneal administration of $\left(m-\mathrm{CF}_{3}-\mathrm{C}_{6} \mathrm{H}_{4} \mathrm{Se}\right)_{2}$ and $\left(p-\mathrm{CH}_{3} \mathrm{O}-\mathrm{C}_{6} \mathrm{H}_{4} \mathrm{Se}\right)_{2}$ inhibited carrageenin-induced paw edema in rats. Different from our expectation the effect of diphenyl diselenide was higher than its disubstituted analogs. ${ }^{65}$

Motivated by a previous reported study showing that $\left(m-\mathrm{CF}_{3}-\mathrm{C}_{6} \mathrm{H}_{4} \mathrm{Se}\right)_{2}$, different from $(\mathrm{PhSe})_{2}$, lacks proconvulsant activity when injected to mice, ${ }^{21}$ Machado and co-workers ${ }^{84}$ have demonstrated that $\left(\mathrm{CF}_{3}-\mathrm{C}_{6} \mathrm{H}_{4} \mathrm{Se}\right)_{2}$ specifically attenuated behavioral features associated with a mouse model of psychosis at a dose that did not affect the behavioral parameters. In a recent study, we provide pharmacological and neurochemical points of evidence for the anxiolytic-like effect elicited by $\left(m-\mathrm{CF}_{3}-\mathrm{C}_{6} \mathrm{H}_{4} \mathrm{Se}\right)_{2}$ in mice. The effective dose to elicit the anxiolytic-like effect was similar for $\left(m-\mathrm{CF}_{3}-\mathrm{C}_{6} \mathrm{H}_{4} \mathrm{Se}\right)_{2}{ }_{25}^{5}$ and diphenyl diselenide. ${ }^{76}$ The involvement of 5- $\mathrm{HT}_{1 \mathrm{~A}}, 5-\mathrm{HT}_{2 \mathrm{~A}}$ and $5-\mathrm{HT}_{3}$ serotonergic receptors as well as a selective inhibition of monoamino oxidase (MAO-A) activity were evidenced in the anxiolytic effect of $\left(m-\mathrm{CF}_{3}-\mathrm{C}_{6} \mathrm{H}_{4} \mathrm{Se}\right)_{2}{ }^{85}$ Our results are in agreement with those of Ghisleni and co-workers ${ }^{77}$ who showed the involvement of $5-\mathrm{HT}_{1 \mathrm{~A}}, 5-\mathrm{HT}_{2 \mathrm{~A} / 2 \mathrm{c}}$ and $\mathrm{GABA}_{\mathrm{A}}$ receptors as potential mechanisms underlying the anxiolytic-like action of diphenyl diselenide. Oral administration of $\left(m-\mathrm{CF}_{3}-\mathrm{C}_{6} \mathrm{H}_{4} \mathrm{Se}\right)_{2}$ was as effective as diphenyl diselenide in protecting against hepatic damage induced by 2-nitropropane in rats. ${ }^{23}$

Following a single hypothesis that the substitution of an $\mathrm{H}$ at the aryl group of diaryl diselenide by an electron withdrawing group would affect the expected effect, recent attention has been brought to the effects of $\left(p-\mathrm{CH}_{3} \mathrm{O}-\right.$ $\left.\mathrm{C}_{6} \mathrm{H}_{4} \mathrm{Se}\right)_{2}$ on chemical models of nociception in mice. These findings suggest that the introduction of an electrondonating substituent in the aromatic ring of diselenide does not alter the pharmacological action of $p-\left(\mathrm{CH}_{3} \mathrm{O}-\mathrm{C}_{6} \mathrm{H}_{4} \mathrm{Se}\right)_{2}$ when compared to diphenyl diselenide but ameliorates its effect in the acetic acid test. ${ }^{86}$

Additionally, we showed that multiple mechanisms are likely to be involved in the $p-\left(\mathrm{CH}_{3} \mathrm{O}-\mathrm{C}_{6} \mathrm{H}_{4} \mathrm{Se}\right)_{2}$ antinociceptive effect. Similar to the mechanisms related to the diphenyl diselenide antinociceptive effect, an interaction with glutamatergic system and protein kinase A (PKA) pathway, nitrergic system, $5 \mathrm{HT}_{3}, \mathrm{D}_{1}, \mathrm{~B}_{1}$ and $\mathrm{B}_{2}$ receptors are involved in $p-\left(\mathrm{CH}_{3} \mathrm{O}-\mathrm{C}_{6} \mathrm{H}_{4} \mathrm{Se}\right)_{2}$ antinociceptive action. ${ }^{87}$ In addition to antinociceptive activity, the hepatoprotective effect of $p-\left(\mathrm{CH}_{3} \mathrm{O}-\mathrm{C}_{6} \mathrm{H}_{4} \mathrm{Se}\right)_{2}$ on acute liver injury induced by lipopolysaccharide/D-galactosamine exposure in mice was reported. ${ }^{88}$ The neuroprotective effect of $p-\left(\mathrm{CH}_{3} \mathrm{O}-\mathrm{C}_{6} \mathrm{H}_{4} \mathrm{Se}\right)_{2}$ was recently demonstrated in a mouse model of sporadic dementia of Alzheimer's type. $p$ - $\left(\mathrm{CH}_{3} \mathrm{O}-\mathrm{C}_{6} \mathrm{H}_{4} \mathrm{Se}\right)_{2}\left(25 \mathrm{mg} \mathrm{kg}^{-1}\right.$, oral $)$ reversed the learning and memory impairments induced by streptozotocin (STZ, intracerebroventricular) in mice. The cerebral activity of acethylcholinesterase stimulated by STZ was ameliorated by $p-\left(\mathrm{CH}_{3} \mathrm{O}-\mathrm{C}_{6} \mathrm{H}_{4} \mathrm{Se}\right)_{2}{ }^{89}$

Disubstituted diselenides, $\left(p-\mathrm{Cl}-\mathrm{C}_{6} \mathrm{H}_{4} \mathrm{Se}\right)_{2}$, $\left(m-\mathrm{CF}_{3}-\mathrm{C}_{6} \mathrm{H}_{4} \mathrm{Se}\right)_{2}, p-\left(\mathrm{CH}_{3} \mathrm{O}-\mathrm{C}_{6} \mathrm{H}_{4} \mathrm{Se}\right)_{2}$ and $(\mathrm{PhSe})_{2}$, were effective in preventing cerebral damage induced by sodium nitroprusside in mice. ${ }^{90}$

Although the pharmacological data on disubstituted diaryl diselenides are still incipient, taken collectively these results suggest that the introduction of an electron donating or an electron withdrawing group into the aryl group of diaryl diselenide did not alter the pharmacological effect of diselenides. Thus, it is possible that the structural modifications in diaryl diselenide molecule do not alter their metabolism, as a consequence disubstituted diaryl diselenide metabolites seem to be generated independent on the substituent bounded to the aryl group of diaryl diselenide.

\section{Conclusions}

Diphenyl diselenide and analogs can partially mimic the "physiological chemistry" of selenium in the mammalian body. Indeed, the antioxidant properties of this class of compounds are associated with the formation of benzeneselenol intermediates after reaction with thiols. The nucleophilicity of benzeneselenol gives to it unique reducing properties in the mammalian cells, which allows the decomposition of potentially toxic peroxides. However, in contrast to selenocysteine residues in selenoproteins, the stability of simple selenol groups are weak and, consequently, the actual concentration of benzeneselenol will be hypothetically low and uncertain. Here we reach to a limitation of the simple organodiselenide/selenol intermediate biochemistry, i.e., the maintenance of the adequate concentration of selenol intermediate will depend on a continuous input of reducing thiol groups. The excessive oxidation of thiol groups by diselenide compounds can be toxic to the living cells. Despite of this, the enormous quantity of in vivo models indicating an antioxidant activity for diphenyl diselenide argues in favor of its therapeutic potential. However, its molecular pharmacology is possibly linked to a "non-specific antioxidant mechanism", where the transient formation of the benzeneselenol plays a central role. Consequently, we can infer that the future of the "biological chemistry of simple diaryl diselenides" will depend on the development of molecules that could generate more stable selenol intermediates. Furthermore, the introduction of 
substituents in the aromatic ring of diaryl diselenides should be oriented to increase the specificity of interaction with specific high molecular weight containing thiols (enzymes, receptors, channels, etc). Other aspect that should be also considered is that the controlled oxidation of thiol- containing enzymes, receptors or channels could be involved in the pharmacological properties of the organochalcogens. For instance, data reported in the literature have suggested that the anti-inflammatory effects of ebselen could be partially mediated by inhibition of protein kinase $\mathrm{C}$ via interaction with thiol groups of the enzyme. ${ }^{91}$ In this scenario, diphenyl diselenide could also interact with specific thiol groups of proteins that participate in the inflammatory process. ${ }^{24}$ Recent indirect data from our research group support an inhibition of protein kinase $\mathrm{C}$ by diaryl diselenides in models of pain in rodents. ${ }^{69,87}$ Taken together, these results indicate that a limited activation of the "toxic pathway", i.e., a nonexcessive or controlled oxidation of specific high molecular weight thiol-containing molecules could contribute to the pharmacological effects of diaryl diselenides. These assumptions reinforce the necessity of developing new diorganoyl diselenides that could interact with specific molecular targets. In summary, the therapeutic potential of diphenyl diselenide and related compounds seems to be superior to their toxic effects, particularly, if one compares their acute anti-inflammatory and antinociceptive activities with their acute lethality in rodents. However, effective pharmacological doses of diselenide compounds can be associated with subtle toxic responses. Consequently, our incipient knowledge about the biochemistry, pharmacology and toxicology of simple diaryl diselenides will improve only after the synthesis of compounds that could interact with specific molecular targets.

\section{Acknowledgments}

The authors wish to sincerely thank their co-workers listed in the references for their dedicated collaboration and devotion. Financial support by UFSM, CAPES, CNPq and FAPERGS is acknowledged. The authors are also thankful to the FINEP research grant "Rede Instituto Brasileiro de Neurociência (IBN-Net)" \# 01.06.0842-00, INCT for Excitotoxicity and Neuroprotection-CNPq and FAPERGS/ CNPq (PRONEX) research grant \# 10/0005-1.

Cristina Wayne Nogueira was born in Santa Maria, Brazil. She received her MSc degree from the Federal University of Santa Maria-RS in 1993 and her PhD (2000) under the direction of Prof. Diogo O. G. Souza (at the Federal University of Rio Grande do Sul). She received a CAPES Postdoctoral Fellowship to work as a postdoctoral

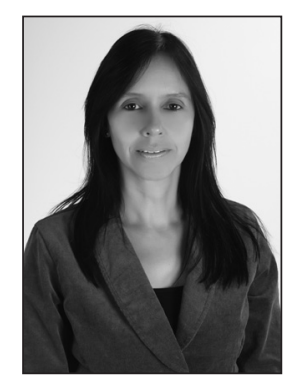

fellow with Prof. J. Thomas at the Iowa State University in 2003. She is currently an Assistant Professor of Biochemistry at the Federal University of Santa Maria. Her current research interests center around the potential role of synthetic organoselenium and tellurium compounds as therapeutic or toxic agents.

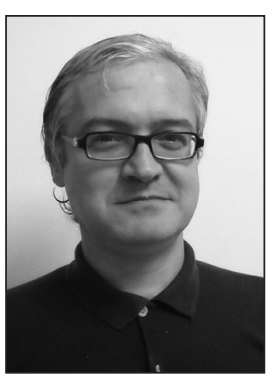

Joao B. T. Rocha was born in Rio de Janeiro. He received his $B S c$ degree in biology in 1987 at the Federal University of Rio Grande do Sul. In 1996, Dr. Rocha received his PhD degree working under the direction of Prof. D. O. Souza. He joined the chemistry department at the Federal University of Santa Maria in 1989, where he is presently a Professor of Biochemistry. In 1997, he received a CNPq Postdoctoral Fellowship to work with Prof. L. De Meis at the Federal University of Rio de Janeiro. His current research interests include the development of new in vitro and in vivo methods to test the toxicity and potential therapeutic use of simple organochalcogenes. The toxicity studies are centered on the reactivity of thiol-containing low weight molecular compounds and proteins, such as ALA-D and LDH with selenium and tellurium organocompounds. The potential antioxidant activities of organocalcogenides are also tested in experimental models of diseases such as diabetes and diskynesia tardia.

\section{References}

1. Arner, E. S.; Biochim. Biophys. Acta 2009, 1790, 495; Araie, H.; Shiraiwa, Y.; Molecules 2009, 14, 4880.

2. Vinceti, M.; Maraldi, T.; Bergomi, M.; Malagoli, C.; Rev. Environ. Health 2009, 24, 231.

3. Muller, A.; Cadenas, E.; Graf, P.; Sies, H.; Biochem. Pharmacol. 1984, 33, 3235.

4. Dawson, D. A.; Masayasu, H.; Graham, D. I.; Macrae, I. M.; Neurosci. Lett. 1995, 185, 65; Yamaguchi, T.; Sano, K.; Takakura, K.; Saito, I.; Shinohara, Y.; Asano, T.; Yasuhara, H.; Stroke 1998, 29, 12; Saito, I.; Asano, T.; Sano, K.; Takakura, K.; Abe, H.; Yoshimoto, T.; Kikuchi, H.; Ohta, T.; Ishibashi, S.; Neurosurgery 1998, 42, 269; Ogawa, A.; Yoshimoto, T.; Kikuchi, H.; Sano, K.; Saito, I.; Yamaguchi, T.;Yasuhara, H.; Cerebrovasc. Dis. 1999, 9, 112.

5. Wilson, S. R.; Zucker, P. A.; Huang, R. R. C.; Spector, A.; J. Am. Chem. Soc. 1989, 111, 5936. 
6. Nogueira, C. W.; Zeni, G.; Rocha, J. B. T.; Chem. Rev. 2004, 104, 6255 .

7. Johansson, L.; Gafvelin, G.; Arnér, E. S.; Biochim. Biophys. Acta 2005, 1726, 1; Pinheiro, M. C. N.; Nascimento, J. L. M.; Silveira, L.; Rocha, J. B. T.; Aschner, M.; Environ. Bioindic. 2009, 4, 222.

8. Frostrom, J. W.; Jackowisk, J. J.; Tappel, A. L.; Biochemistry 1978, 17, 2639.

9. Lu, J.; Holmgren, A.; J. Biol. Chem. 2009, 284, 723.

10. Barbosa, N. B. V.; Rocha, J. B. T.; Beque, M.; Emanuelli, T.; Zeni, G.; Braga, A. L.; Toxicol. Appl. Pharmacol. 1998, 149, 243.

11. Maciel, E. N.; Bolzan, R. C.; Braga, A. L.; Rocha, J. B. T.; J. Biochem. Mol. Toxicol. 2000, 14, 310.

12. Folmer, V.; Bolzan, R. C.; Farina, M.; Zeni, G.; Nogueira, C. W.; Emanuelli, T.; Rocha, J. B. T.; Toxicology 2005, 206, 403.

13. Kade, I. J.; Paixão, M. W.; Rodrigues, O. E.; Barbosa, N. B.; Braga, A. L.; Ávila, D. S.; Nogueira, C. W.; Rocha, J. B. T.; Neurochem. Res. 2008, 33, 167.

14. Nogueira, C. W.; Borges, V. C.; Zeni, G.; Rocha, J. B. T.; Toxicology 2003, 191, 169; Borges, V. C.; Rocha, J. B. T.; Nogueira, C. W.; Toxicology 2005, 215, 191; Farina, M.; Barbosa, N. B.; Nogueira, C. W.; Folmer, V.; Zeni, G.; Andrade, L. H.; Braga, A. L.; Rocha, J. B. T.; Braz. J. Med. Biol. Res. 2002, 35, 623; Soares, F. A.; Farina, M.; Boettcher, A. C.; Braga, A. L.; Rocha, J. B. T.; Environ. Res. 2005, 98, 46; Golombieski, R. M.; Graichen, D. A.; Pivetta, L. A.; Nogueira, C. W.; Loreto, E. L.; Rocha, J. B. T.; Comp. Biochem. Physiol. C, Toxicol. Pharmacol. 2008, 147, 198; Lugokeski, T.; Muller, L.; Taube, P.; Rocha, J. B. T.; Pereira, M. E.; Drug Chem. Tox. 2010, DOI: 10.3109/01480541003782294; Puntel, R. L.; Roos, D. H.; Folmer,V.; Nogueira, C. W.; Galina, A.; Aschner, M.; Rocha, J. B. T.; Toxicol. Sci. 2010, DOI:10.1093/toxsci/kfq185.

15. Kade, I. J.; Paixão, M. W.; Rodrigues, O. E.; Ibukun, E. O.; Braga, A. L.; Zeni, G.; Nogueira, C. W.; Rocha, J. B. T.; Toxicol. Vitro 2009, 23, 14.

16. Rossato, J. I.; Ketzer, L. A.; Centurião, F. B.; Silva, S. J.; Lüdtke, D. S.; Zeni, G.; Braga, A. L.; Rubin, M. A.; Rocha, J. B. T.; Neurochem. Res. 2002, 27, 297; Puntel, R. L.; Roos, D. H.; Paixão, M. W.; Braga, A. L.; Zeni, G.; Nogueira, C. W.; Rocha, J. B. T.; Chem. Biol. Interact. 2007, 165, 87; de Bem, A.F.; Farina, M.; Portella, R. L.; Nogueira, C. W.; Dinis, T. C.; Laranjinha, J. A.; Almeida, L. M.; Rocha, J. B. T.; Atherosclerosis 2008, 201, 92; Hassan, W.; Ibrahim, M.; Deobald, A. M.; Braga, A. L.; Nogueira, C. W.; Rocha, J. B. T.; FEBS Lett. 2009, 583,1011; Hassan, W.; Ibrahim, M.; Nogueira, C. W.; Braga, A. L.; Mohammadzai, I. U.; Taube, P. S.; Rocha, J. B. T.; Brain Res. 2009, 1258, 71; Ogunmoyole, T.; Rocha, J. B. T.; Okoronkwo, A. E.; Kade, I. J.; Chem. Biol. Interact. 2009, 182, 106; Posser, T.; Moretto, M. B.; Dafre, A. L.; Farina, M.; da Rocha, J. B. T.; Nogueira, C. W.; Zeni,
G.; Ferreira, J. dos S.; Leal, R. B.; Franco, J. L.; Chem. Biol. Interact. 2006, 164, 126; Hassan, W.; Ibrahim, M.; Rocha, J. B. T.; Pathol. Res. Pract. 2010, 206, 357.

17. Posser, T.; Franco, J. L.; dos Santos, D. A.; Rigon, A. P.; Farina, M.; Dafré, A. L.; Rocha, J. B. T.; Leal, R. B.; Brain Res. 2008, 119, 138.

18. Aschner, M.; Syversen, T.; Souza, D. O.; Rocha, J. B.; Farina, M.; Braz. J. Med. Biol. Res. 2007, 40, 285.

19. Roos, D. H.; Puntel, R. L.; Santos, M. M.; Souza, D. O.; Farina, M.; Nogueira, C. W.; Aschner, M.; Burger, M. E.; Barbosa, N. B.; Rocha., J. B. T.; Toxicol. Vitro 2009, 23, 302.

20. Meotti, F. C.; Borges, V. C.; Zeni, G.; Rocha, J. B. T.; Nogueira, C. W.; Toxicol. Lett. 2003, 143, 9.

21. Nogueira, C. W.; Meotti, F. C.; Curte, E.; Pilissao, C.; Zeni, G.; Rocha, J. B. T.; Toxicology 2003, 183, 29.

22. Wendel, A.; Fausel, M.; Safayhi, H.; Tiegs, G.; Otter, R.; Biochem. Pharmacol. 1984, 33, 3241.

23. Wilhelm, E. A.; Jesse, C. R.; Nogueira, C. W.; Savegnago, L.; Exp. Toxicol. Pathol. 2009, 61, 197.

24. Savegnago, L.; Pinto, L. G.; Jesse, C. R.; Alves, D.; Rocha, J. B. T.; Nogueira, C. W.; Zeni, G.; Eur. J. Pharmacol. 2007, 555, 129.

25. Savegnago, L.; Jesse, C. R.; Nogueira, C. W.; Environ. Toxicol. Pharm. 2009, 27, 271.

26. Jacques-Silva, M. C.; Nogueira, C. W.; Broch, L. C.; Flores, E. M. M.; Rocha, J. B. T.; Pharmacol. Toxicol. 2001, 88, 119; Maciel, E. N.; Flores, E. M. M.; Rocha, J. B. T.; Folmer, V.; Bull. Environ. Contam. Toxicol. 2003, 70, 470; Prigol, M.; Pinton, S.; Schumacher, R.; Nogueira, C.W.; Zeni, G.; Arch. Toxicol. 2010, 84, 373.

27. Prigol, M.; Wilhelm, E. A.; Schneider, C. C.; Rocha, J. B. T.; Nogueira, C. W.; Zeni, G.; Brain Res. 2007, 147, 226.

28. Prigol, M.; Schumacher, R. F.; Nogueira, C. W.; Zeni, G.; Toxicol. Lett. 2009, 189, 35.

29. Nogueira, C. W.; Rotta, L. N.; Perry, M. L.; Souza, D. O.; Rocha, J. B. T.; Brain Res. 2001, 906, 157; Nogueira, C. W.; Rotta, L. N.; Zeni, G.; Souza, D. O.; Rocha, J. B. T.; Neurochem. Res. 2002, 27, 283; Moretto, M. B.; Rossato, J. I.; Nogueira, C. W.; Zeni, G.; Rocha, J. B. T.; J. Biochem. Mol. Toxicol. 2003, 17, 154; Moretto, M. B.; Thomazi, A. P.; Godinho, G.; Roessler, T. M.; Nogueira, C. W.; Souza, D. O.; Wofchuk, S.; Rocha, J. B. T.; Toxicol. Vitro 2007, 21, 639; Ardais, A. P.; Viola, G. G.; Costa, M. S.; Nunes, F.; Behr, G. A.; Klamt, F.; Moreira, J. C. F.; Souza, D. O.; Rocha, J. B. T.; Porciuncula, L. O.; Toxicol. Sci. 2010, 113, 434.

30. Favero, A. M.; Weis, S. N.; Stangherlin, E. C.; Zeni, G.; Rocha, J. B.; Nogueira, C. W. ; Reprod. Toxicol. 2005, 20, 561; Favero, A. M.; Weis, S. N.; Stangherlin, E. C.; Zeni, G.; Rocha, J. B.; Nogueira, C. W.; Reprod. Toxicol. 2007, 23, 119.

31. Weis, S. N.; Favero, A. M.; Stangherlin, E. C.; Rocha, J. B. T.; Nogueira, C. W.; Zeni, G.; Reprod. Toxicol. 2007, 23, 175. 
32. Favero, A. M.; Weis, S. N.; Zeni, G.; Rocha, J. B. T.; Nogueira, C. W.; Neurotoxicol. Teratol. 2006, 28, 607.

33. Stangherlin, E. C.; Favero, A. M.; Weis, S. N.; Zeni, G.; Rocha, J. B.; Nogueira, C. W.; Food Chem. Toxicol. 2006, 44, 662; Favero, A. M.; Weis, S. N.; Stangherlin, E. C.; Zeni, G.; Rocha, J. B.; Nogueira, C. W.; Reprod. Toxicol. 2007, 23, 119.

34. Lu, S. C.; FASEB J. 1999, 13, 1169.

35. Lu, S. C.; Mol. Aspects Med. 2009, 30, 42.

36. Brandao, R.; Santos, F. W.; Zeni, G.; Rocha, J. B. T.; Nogueira, C. W.; Biometals 2006, 19, 389.

37. Rosa, R. M.; Hoch, N. C.; Furtado, G. V.; Saffi, J.; Henriques, J. A. P.; Mutat. Res. Genet. Toxicol. Environ. Mutagen 2007, 633, 35.

38. Rocha, J. B. T.; Gabriel, D.; Zeni, G.; Posser, T.; Siqueira, L.; Nogueira, C. W.; Folmer, V.; Environ. Toxicol. Pharmacol. 2005, 19, 255.

39. Perottoni, J.; Meotti, F.C.; Folmer, V.; Pivetta, L.; Nogueira, C.W.; Zeni, G.; Rocha, J. B. T.; Environ. Toxicol. Pharmacol. 2005, 19, 239.

40. Richie, J. P.; Kleinman, W.; Desai, D. H.; Das, A.; Amin, S. G.; Pinto, J. T.; El-Bayoumy, K.; Chem. BioI. Interact. 2006, 161, 93.

41. Barbosa, N. B. V.; Rocha, J. B. T.; Wondracek, D. C.; Perottoni, J.; Zeni, G.; Nogueira, C. W.; Chem. Biol. Interact. 2006, 163, 230; Luchese, C.; Stangherlin, E. C.; Ardais, A. P.; Nogueira, C. W.; Santos, F. W.; Toxicology 2007, 230, 189; Luchese, C.; Stangherlin, E. C.; Gay, B. M.; Nogueira, C. W.; Ecotoxicol. Environ. Safety 2009, 72, 248; Luchese, C.; Pinton, S.; Nogueira, C. W.; Pharmacol. Res. 2009, 59, 194.

42. de Bem, A. F.; Portella, R. D. L.; Perottoni, J.; Becker, E.; Bohrer, D.; Paixao, M. W.; Nogueira, C. W.; Zeni, G.; Rocha, J. B. T.; Chem. Biol. Interact. 2006, 162, 1.

43. Brandao, R.; Santos, F. W.; Oliveira, R.; Roman, S. S.; Nogueira C. W.; J. Trace Elem. Med. Biol. 2009, 23, 324; Prigol, M.; Luchese, C.; Nogueira, C. W.; Cell Biochem. Funct. 2009, 27, 216.

44. Fachinetto, R.; Pivetta, L. A.; Farina, M.; Pereira, R. P.; Noguelra, C. W.; Rocha, J. B. T.; Food Chem. Toxicol. 2006, 44,588 .

45. de Vargas Barbosa, N. B.; Oliveira, C.; Araldi, D.; Folmer, V.; Rocha, J. B. T.; Nogueira, C. W.; Biol. Pharm. Bull. 2008, 31 2200; Prigol, M.; Wilhelm, E. A.; Stangherlin, E. C.; Barancelli, D. A.; Nogueira, C. W.; Zeni, G.; Neurochem. Res. 2008, 33, 996.

46. Meotti, F. C.; Borges, V. C.; Perottoni, J.; Nogueira, C. W.; J. Appl. Toxicol. 2008, 28, 638.

47. de Bem, A. F.; Portella, R. D.; Farina, M.; Perottoni, J.; Paixao, M. W.; Nogueira, C. W.; Rocha, J. B. T.; Basic Clin. Pharmacol. Toxicol. 2007, 101, 47; Straliotto, M. R.; Mancini, G.; de Oliveira, J.; Nazari, E. M.; Müller, Y. M. R.; Dafre, A.; Ortiz, S.; Silva, E. L.; Farina, M.; Latini, A.; Rocha, J. B. T.; de Bem, A. F.; J. Appl. Toxicol. 2010, DOI 10.1002/jat.1560.
48. Bechara, E. J. H.; Dutra, F.; Cardoso, V. E. S.; Sartori, A.; Olympio, K. P. K.; Penatti, C. A. A.; Adhikari, A.; Assunção, N. A.; Comp. Biochem. Physiol. 2007, 146, 88.

49. Rocha, M. E. M.; Dutra, F.; Bandy, B.; Baldini, R. L.; Gomes, S. L.; Faljoni-Alario, A.; Liria, C. W.; Miranda, M. T. M.; Bechara, E. J. H.; Arch. Biochem. Bioph. 2003, 409, 349; Rocha, M. E. M.; Bandy, B.; Costa, C. A.; de Barros, M. P.; Pinto, A. M. P.; Bechara, E. J. H.; Free Radic. Res. 2000, 32, 343; Emanuelli, T.; Prauchner, C. A.; Dacanal, J.; Zeni, A.; Reis, E. C.; de Mello, C. F.; de Souza, D. O.; Brain Res. 2000, 868, 88; Emanuelli, T.; Pagel, F. W.; Porciuncula, L. O.; Souza, D. O.; Neurochem. Int. 2003, 42, 115.

50. Pearson, R. G.; Songstad, J.; J. Am. Chem. Soc. 1967, 89, 1827.

51. Sugiura, Y.; Hojo, Y.; Tamai, Y.; Tanaka, H. ; J. Am. Chem. Soc. 1976, 98, 2339.

52. Brandão, R.; Borges, L. P.; Oliveira, R.; Rocha, J. B. T.; Nogueira, C. W.; J. Biochem. Mol. Toxicol. 2008, 22, 311.

53. Brandão, R.; Borges, L. P.; Nogueira, C. W.; Food Chem. Toxicol. 2009, 47, 1771.

54. de Freitas, A. S.; Funck, V. R.; Rotta, M. D.; Bohrer, D.; Morschbacher, V.; Puntel, R. L.; Nogueira, C. W.; Farina, M.; Aschner, M.; Rocha, J. B. T.; Brain Res. Bull. 2009, 79, 77.

55. Farina, M.; Dahm, K. C.; Schwalm, F. D.; Brusque, A. M.; Frizzo, M. E.; Zeni, G.; Souza, D. O.; Rocha, J. B. T.; Toxicol. Sci. 2003, 73, 135; Farina, M.; Frizzo, M. E.; Soares, F. A.; Schwalm, F. D.; Dietrich, M. O.; Zeni, G.; Rocha, J. B. T.; Souza, D. O.; Toxicol. Lett. 2003, 144, 351.

56. Flora, S. J.; Mittal, M.; Mehta, A.; Indian J. Med. Res. 2008, $128,501$.

57. Santos, F. W.; Oro, T.; Zeni, G.; Rocha, J. B. T.; do Nascimento, P. C.; Nogueira, C. W.; Toxicol. Lett. 2004, 152, 255.

58. Santos, F. W.; Zeni, G.; Rocha, J. B. T.; do Nascimento, P. C.; Marques, M. S.; Nogueira, C. W.; Food Chem. Toxicol. 2005, $43,1723$.

59. Santos, F. W.; Zeni, G.; Rocha, J. B. T.; Weis, S. N.; Fachinetto, J. M.; Favero, A. M.; Nogueira, C. W.; Chem. Biol. Interact. 2005, 151, 159.

60. Santos, F. W.; Graça, D. L.; Zeni, G.; Rocha, J. B. T.; Weis, S. N.; Favero, A. M.; Nogueira, C. W.; Reprod. Toxicol. 2006, 22, 546.

61. Borges, L. P.; Brandão, R.; Godoi, B.; Nogueira, C. W.; Zeni, G.; Chem. Biol. Interact. 2008, 171, 15.

62. Luchese, C.; Brandao, R.; Oliveira, R.; Nogueira, C. W.; Santos, F. W.; Toxicol. Lett. 2007, 173, 181.

63. Silveira, C. C.; Braga, A. L.; Larghi, E. L.; Organometallics 1999, 18, 5183.

64. Spallholz, J. E.; Free Radic. Biol. Med. 1994, 17, 45; ElBayoumy, K.; Upadhyaya, P.; Fiala, E.; Rao, C. V.; Anticancer Res. 1996, 16, 1123.

65. Nogueira, C. W.; Quinhones, E. B.; Jung, E. A. C.; Zeni, G.; Rocha, J. B. T.; Inflamm. Res. 2003, 52, 56. 
66. Savegnago, L.; Jesse, C. R.; Santos, A. R. S.; Rocha, J. B. T.; Nogueira, C. W.; J. Pharm. Pharmacol. 2008, 60, 1679.

67. Zasso, F. B.; Goncales, C. E. P.; Jung, E. A. C.; Araldi, D.; Zeni, G.; Rocha, J. B. T.; Nogueira, C. W.; Environ. Toxicol. Pharmacol. 2005, 19, 283.

68. Di Rosa, M.; Giroud, J. P.; Willoughby, D. A.; J. Pathol. 1971, 104, 15.

69. Savegnago, L.; Jesse, C. R.; Pinto, L. G.; Rocha, J. B. T.; Nogueira, C. W.; Brain Res. 2007, 1175, 54.

70. Savegnago, L.; Pinto, L. G.; Jesse, C. R.; Rocha, J. B. T.; Nogueira, C. W.; Zeni, G.; Brain Res. 2007, 1162, 32.

71. Savegnago, L.; Jesse, C. R.; Nogueira, C. W.; Neurosci. Lett. 2008, 436, 120.

72. Borges, L. P.; Borges, V. C.; Moro, A. V.; Nogueira, C. W.; Rocha, J. B. T.; Zeni, G.; Toxicology 2005, 210, 1; Borges, L. P.; Nogueira, C. W.; Panatieri, R. B.; Rocha, J. B. T.; Zeni, G.; Chem. Biol. Interact. 2006, 160, 997.

73. Savegnago, L.; Trevisan, M.; Alves, D.; Rocha, J. B. T.; Nogueira, C. W.; Zeni, G.; Environ. Toxicol. Pharmacol. 2006, 21, 86; Ineu, R. P.; Pereira, M. E.; Aschner, M.; Nogueira, C. W.; Zeni, G.; Rocha, J. B. T.; Food Chem. Toxicol. 2008, 46, 3023.

74. Barbosa, N. B. D.; Nogueira, C. W.; Guecheva, T. N.; Bellinaso, M. D.; Rocha, J. B. T.; Arch. Toxicol. 2008, 82, 655.

75. Brandao, R.; Acker, C. I.; Leite, M. R.; Barbosa, N. B. V.; Nogueira, C. W.; J. Appl. Toxicol. 2009, 29, 612.

76. Savegnago, L.; Jesse, C. R.; Pinto, L. G.; Rocha, J. B. T.; Barancelli, D. A.; Nogueira, C. W.; Zeni, G.; Pharmacol. Biochem. Behav. 2008, 88, 418.

77. Ghisleni, G.; Kazauckas, V.; Both, F. L.; Pagnussat, N.; Mioranzza, S.; Rocha, J. B. T.; Souza, D. O.; Porciuncula, L. O.; Prog. Neuro-Psychopharmacol. Biol. Psychiatry 2008, 32, 1508.

78. Acker, C. I.; Luchese, C.; Prigol, M.; Nogueira, C. W.; Neurosci. Lett. 2009, 455, 168.
79. Rosa, R. M.; Flores, D. G.; Appelt, H. R.; Braga, A. L.; Henriques, J. A. P.; Roesler, R.; Neurosci. Lett. 2003, 341, 217.

80. Stangherlin, E. C.; Luchese, C.; Pinton, S.; Rocha, J. B. T.; Nogueira, C. W.; Brain Res. 2008, 1201, 106.

81. Burger, M. E.; Fachinetto, R.; Wagner, C.; Perottoni, J.; Pereira, R. P.; Zeni, G.; Rocha, J. B. T.; Brain Res. Bull. 2006, 70, 165.

82. de Bem, A. F.; Portella, R. D.; Colpo, E.; Duarte, M. M. M. F.; Frediane, A.; Taube, P. S.; Nogueira, C. W.; Farina, M.; da Silva, E. L.; Rocha, J. B. T.; Basic Clin. Pharmacol. Toxicol. 2009, 105, 17.

83. da Rocha, J. T.; Sperança, A.; Nogueira, C. W.; Zeni, G.; J. Pharm. Pharmacol. 2009, 61, 1673.

84. Machado, M. S.; Rosa, R. M.; Dantas, A. S.; Reolon, G. K.; Appelt, H. R.; Braga, A. L.; Henriques, J. A. N.; Roesler, R.; Neurosci. Lett. 2006, 410, 198.

85. Bruning, C. A.; Prigol, M.; Roehrs, J. A.; Nogueira, C. W.; Zeni, G.; Behav. Brain Res. 2009, 205, 511.

86. Pinto, L. G.; Jesse, C. R.; Nogueira, C. W.; Savegnago, L.; Pharmacol. Biochem. Behav. 2008, 88, 487.

87. Jesse, C. R.; Rocha, J. B. T.; Nogueira, C. W.; Savegnago, L.; Pharmacol. Biochem. Behav. 2009, 91, 573.

88. Wilhelm, E. A.; Jesse, C. R.; Nogueira, C. W.; Fund. Clin. Pharmacol. 2009, 23, 727.

89. Pinton, S.; da Rocha, J. T.; Zeni, G.; Nogueira, C. W.; Neurosci. Lett. 2010, 472, 56.

90. Prigol, M.; Bruning, C. A.; Zeni, G.; Nogueira, C. W.; Biochem. Eng. J. 2009, 45, 94.

91. Cotgreave, I. A.; Duddy, S. K.; Kass, G. E. N.; Thompson, D.; Moldeus, P.; Biochem. Pharmacol. 1989, 38, 649.

Submitted: March 25, 2010

Published online: August 10, 2010 